\title{
NOMINAL COMPOSITION IN MYCENAEAN GREEK ${ }^{1}$
}

\author{
By Torsten Meissner and Olga Tribulato \\ Pembroke College, Cambridge
}

\begin{abstract}
Nominal composition is an extremely productive means of word formation in Ancient Greek. Little has been written about it in English. Therefore, the present article gives a short introduction to nominal composition in this language in general before moving on to the earliest attested stage of the language, Mycenaean. An overview of nominal compounds of Mycenaean Greek is given and a classification attempted. Thereafter, issues in their phonology and morphology are discussed and both the similarities with and differences to later Greek established. It is concluded that Mycenaean, while preserving some archaic types, is already far advanced in the development of nominal composition typical for Greek.
\end{abstract}

\section{Introduction: Nominal COMPOSITION IN GReEK}

There are few ancient Indo-European languages where nominal composition (NC) plays a more prominent role in word formation than Greek. This is true both for the range of compositional types attested and their productivity. Yet, although a significant amount of work has been done on NC in Ancient Greek, the only comprehensive account to date is that by $T \sigma \epsilon \rho \epsilon \in \pi \eta s$ (second edition 1902). This work is necessarily somewhat out-of-date but it is still useful for general reference and as a collection of evidence. On the other hand, NC in particular authors and genres, as well as compositional types or aspects of $\mathrm{NC}$, has received considerable

1 The authors would like to thank Prof. J.T. Killen for corrections and helpful comments. 
attention. $^{2}$ By far the most important study is Risch's 1974 exposition which not only gives an exemplary overview and provides what is now the standard classification of Homeric compounds but also addresses many issues in the morphology, syntax and semantics of Greek NC in general. ${ }^{3}$

\section{The Study of NC in Mycenaean GreeK}

As with many aspects of the Greek language, NC received an additional historical dimension through the decipherment of Linear B. Yet, NC in Mycenaean (Myc.) has hitherto been dealt with only cursorily or with a view to very specific issues. ${ }^{4}$

It is important to bear in mind the external constraints of an investigation of $\mathrm{NC}$ in Myc. This early form of Greek can give valuable clues as to the development and early history of $\mathrm{NC}$ in the language and sometimes even serve as a link between historical

${ }^{2}$ It is beyond the scope of this paper to give a complete account of studies of Greek $\mathrm{NC}$; a short but very good and useable synoptic view with numerous references is found in Meier-Brügger (1992) II, 33-39. Reference is made to publications of major interest in what follows.

3 Turning to earlier, author-specific works on NC: for the Archaic and Classical periods, in addition to the above, the following are of particular importance. Homer: van Strien-Gerritsen 1973, Magnien 1927, Stolz 1874; Hesiod: Troxler 1964, Stolz 1874; Pindar: Glaser 1898, Tessing 1884; tragedy: Williger 1928, Richards 1918, Bielecki 1899, Tessing 1884, Schultz 1882, Rieck 1877, Roemheld 1877; Aristophanes: da Costa Ramalho 1952, Bielecki 1899; Herodotus: Karassek 1880; Thucydides: Holmes 1893.

For the study of compositional types, the following are particularly noteworthy:

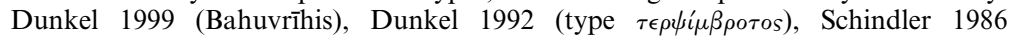
(



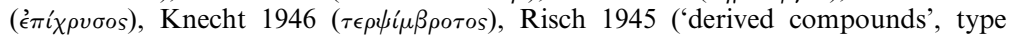

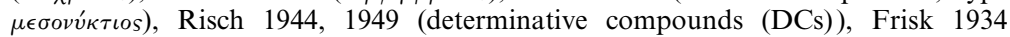

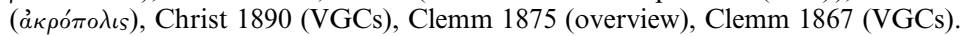

Specific issues are dealt with in Schindler 1997 (internal syntax), Sommer 1948 (thematisation), Hatzidakis 1900 and von Schroeder 1877 (accentuation), Wackernagel 1889 (Kompositionsfuge), Neckel 1882 (case compounds). These works are only a selection but may serve as a first point of orientation.

${ }^{4}$ Vilborg 1960 gives an overview of the most important categories and formations (pp. 140-142); Bader 1965 concentrates on compounds with a first member meaning 'good'. Bader 1971 and Risch 1983 look at the Kompositionsfuge, and more recently Buzalkovska-Aleksova 1999 discusses some parallel lexical elements in compounded personal names (PNs) and appellative compounds in Myc. 
Greek and PIE in this respect. Yet a comparison between Myc. and later forms of Greek is not unproblematic, given the obvious chronological gap between Myc. and the later Greek evidence as well as the different nature of the texts concerned. Most of the work done has concentrated on NC in literary texts, and with good reason. It is obvious that the Vedic hymns or the Homeric epics are full of compounds, many of them of an archaic flavour, and NC has often been defined as a prominent feature of poetic style. But this should not be over-stressed to the point of identifying $\mathrm{NC}$ in toto with poetic language, thus implicitly assuming that everyday communication and written attestations of a non-literary level (inscriptions, papyri, laws etc.) were immune from $\mathrm{NC} .^{5}$

The only type of evidence available for Myc. is, of course, epigraphic and it is precisely these texts of lower provenance that have otherwise been neglected for the study of NC. Yet such texts could cast light on the actual use and productivity of this means of word formation as a feature of non-literary language and not simply as a form of poetic expression.

A study of Myc. NC has thus become more and more important both as a point of comparison for the Homeric evidence and because it allows us to assess the status of NC in non-literary, if standardised and maybe not entirely unambitious, bureaucratic texts. Although some work has been done on this topic in the last fifty years, the ever-increasing evidence calls out for the collection of data and its discussion, both from the point of view of its morphology and of the role played by $\mathrm{NC}$ in Myc. as a language. A truly comprehensive study of Myc. compounds would require more time and space than is allowed here, particularly because of the considerable number of problems involved in the semantic, phonological and morphological interpretation of many Myc. words. Nonetheless, some considerations and preliminary conclusions are possible.

5 This view is common, cf. Meillet-Vendryès 1963: 421: 'La langue populaire n'emploie guère la composition. Les textes littéraires présentent en général d'autant plus de composés qu'ils s'éloignent davantage de l'usage courant. Le composé a le plus souvent quelque chose d'artificiel; il convient aux langues spéciales et techniques de la philosophie, de la science (. . . ) auxquelles il confère à la fois précision et gravité. C'est surtout la langue poétique qui en fait usage. Les poètes qui se piquent d'un langage noble et veulent atteindre un ton élevé, obtiennent l'effet cherché en employant des composés'. 


\section{SCOPE OF THIS ARTICLE}

Comparatively little has been written on Greek NC in English, and after a general introduction to the topic we will focus on the identification and classification of Myc. compounds, noting both their similarities with and divergences from later Greek: in the case of the latter, some correspondences between Myc. and Sanskrit that are lost in later Greek will be discussed. Thus, the compositional categories of Greek will briefly be described and some theoretical problems concerning the formal and syntactic definition of a compound will be dealt with. Some Myc. evidence will also be used to describe the status of $\mathrm{NC}$ in second millennium Greek. The final section will deal with some questions regarding the morphology and phonetics of NC in Myc.

This study is based on a survey of all the Myc. compounds present in DMic. Here, of course, our problems begin. Owing to the ambiguities of the script, the variations in spelling and word division (see also section 6.2.) and frequently also the absence of a clear textual context, the identification and interpretation of a word as a compound is often far from secure. This is true in particular for PNs where contextual evidence is lacking almost by definition, and these will be used very sparingly in the following discussion. As far as the appellative lexicon is concerned, almost all forms of uncertain interpretation have been included, when the balance of likelihood suggests that they are compounds. Errors and omissions are still possible, in particular with respect to the evidence from Thebes that has not or not satisfactorily been edited.

The forms are normally quoted without reference to the tablet(s) of attestation: this can be checked against DMic., and the Myc. indices; the former is also the principal point of reference for meaning, unless otherwise stated.

\section{Compositional categories of Greek}

\subsection{Criteria of classification: a combination of structure and meaning}

Greek nominal compounds, like those of other languages, can be classified according to two criteria: their meaning (suggested by the 
syntactic and logical relation between the members) and their form, i.e. the morphological elements involved in the make-up of a compound. These two factors are principally independent of one another and can be analysed from the point of view of their own

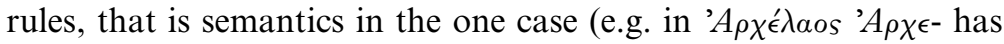

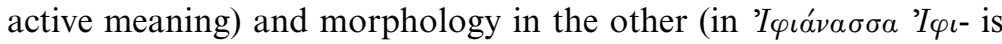
an instrumental plural). However, when they are studied as compositional elements, a formal description must be linked to the syntactic criterion, for, as Benveniste 1967: 16 states 'la structure est agencée par la relation. Seule la relation logique fournit les critères propres à classer fonctionnellement les types de composés.' So, for example, the presence of a preposition as the first member (FM) is not a marker per se of a 'prepositional' compound. It is the relation that this preposition has with the second member (SM) and thus the meaning of the whole compound that determines its status. A compound must not be considered 'rien autre qu'une variété de la formation des noms, au même titre que la dérivation', even though 'les particularités formelles des mots composés intéressent en effet la morphologie nominale, notamment les variations étant justement une des marques, parfois la marque unique de la composition'. But 'la considération morphologique laisse sans réponse et $(. .$.$) ne$ permet même de poser le problème fondamental: quelle est la fonction des composés? (. . .) Pour répondre à cette question il faut (. . .) envisager les composés non plus comme des espèces morphologiques, mais comme des organisations syntaxiques. La composition nominale est une micro-syntaxe.' (Benveniste 1967: 15).

The semantic criterion is the classification adopted by Indian grammarians to describe the compositional categories of Sanskrit, and is still the background for every modern work on NC in Greek


languages (Wackernagel Ai.Gr. for Sanskrit, Uhlich 1993 for Old Irish). This is partly due to the absence of theoretical discussion by ancient Greek grammarians who limit their analysis to a distinction between $\sigma v ́ v \theta \epsilon \tau \alpha$ ('compounds') and $\pi \alpha \rho \alpha \dot{\theta} \epsilon \tau \alpha$ ('juxtapositions', Schwyzer 1939: 428).

In modern works, formal and semantic criteria are combined, and the number of categories has been expanded. Sanskrit grammarians, 
for instance, did not recognise compounds with a verbal member

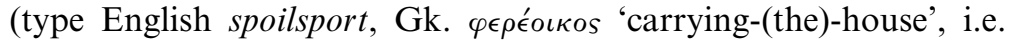
'snail') as a distinct category, to be distinguished from nominal

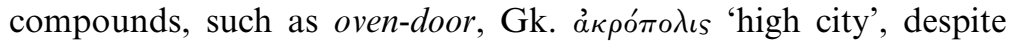
that fact that the relationship between the members is very different in these two compound types. In the former type, one element (the verbal one) governs the other (governing compounds); in the second, the first member modifies the second, the head, inasmuch as it narrows or specifies the concept of the head. These are the nominal compounds in the stricter sense of the word. But within this category, many further subdivisions can be made, depending on the form and semantics of the compound concerned.

The current classification of compounds is thus partly formal as it pays attention to the kinds of word or stem contained in a compound, and is partly governed by syntax and semantics:

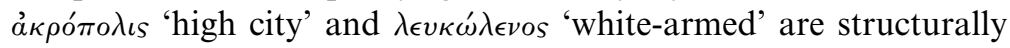
very similar as they both contain a combination of adjective (modifier) + noun (head) but there is an obvious difference: the former is a noun, the latter an adjective.

\subsection{Structure}

Although structure is not independent of semantics, it is a criterion that must be described and discussed according to morphological rules. A formal consideration is that almost all kinds of words can serve as members of a compound (nominal or verbal stems; adjectives; prepositions or prefixes; numerals etc.): this is not influenced by syntax.

When the FM is a noun, it can have a case ending. This is a phenomenon common to almost all categories of compounds but seems particularly frequent in the case of DCs; it may be due to their old status as juxtapositions (cf. 5.4). Typically, though, in the case of composition in Greek as well as in the other early-attested IE languages, the first member of a nominal compound appears in a bound form, the mere stem, i.e. root + derivational suffix(es), without an inflectional ending. Yet one must be cautious when drawing conclusions based on the common assumption that composition is 
in origin pre-inflectional, ${ }^{6}$ a relic of a stage when PIE had no endings, and that compounds containing inflected forms must be considered to be later univerbations. This may well be true in principle and prototypically, but for our purposes the chronological priority of certain forms over others (e.g. root compounds versus univerbations) is less relevant, given that some univerbations (such as *dems-potis 'house-master') may well be very old indeed. Thus, at the same chronological level, both root/stem and inflected forms are found (Dunkel 1999). The commonly held distinction between juxtaposition and 'real' composition (i.e. stem composition) is thus not necessarily always helpful for the synchronic analysis of Greek compounds.

\subsection{Determination vs. addition; centricity}

The relationship between the members of a nominal compound is important from a semantic point of view, but it also has syntactic implications. For a start, the logical relationship between the members can be additive, $\nu v \chi \theta \eta^{\prime} \mu \epsilon \rho o v$ 'night and day, 24 hours': 'copulative compounds' or 'Dvandva' (see the article by Sadovski in this volume). This type is very rare in Greek and as no example from Myc. has, as yet, been found, it is beyond the scope of our discussion. The vast majority of nominal compounds are of the

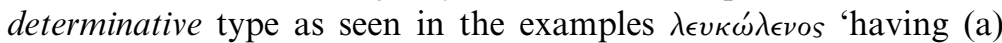


of the relationship between the members is the question of 'centricity': 7 a compound can be 'endocentric' (if the result of the process of composition is contained within the compound itself) or 'exocentric' (if the actual item the compound refers to lies outside the compound itself, implying a function and thus a meaning which

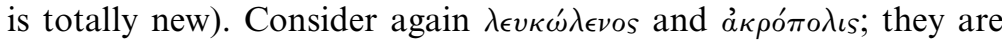
syntactically identical from a compound-internal point of view, but very different when it comes to their centricity: $\lambda \epsilon v \kappa \omega \dot{\lambda} \epsilon \epsilon \nu$ os expresses an external idea not 'white arm' but an X, not contained in the



6 This view is expressed by Schwyzer 1939: 428.

7 See in particular Schwyzer 1939: 429, Uhlich 1993: 78. 
contrast, conveys an internal idea: 'high city', i.e. still a noun and still a type of city. These exocentric compounds are commonly known as 'Bahuvrīhis' (Bs, the word itself is borrowed from Sanskrit terminology, meaning 'having much rice', i.e. 'rich'; see again Sadovski in this volume); they are typically adjectives (indeed, this is arguably what 'exocentric' means) but can also be used as

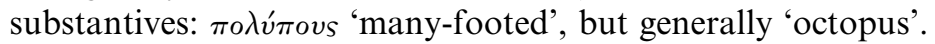

It is worth bearing in mind that the established classification is misleading: the Sanskrit grammarians distinguish Bs from DCs, despite the fact that in the great majority of instances in Bs, the relationship is of the determinative type. We mention in passing that

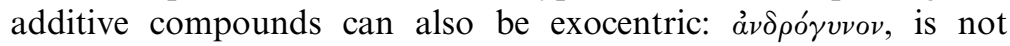
'man and woman', but rather 'a being who has features of both, hermaphrodite'. However, such compounds are extremely rare in Greek and need not be treated further here. ${ }^{8}$

\subsection{Nominal compounds expressing determination}

\subsubsection{Possessive compounds (= B)}

Bs, having a meaning 'whose SM is (like/like that of) FM', are extremely productive in Greek. Their original function as adjectives has already been outlined above and is evident in words such as

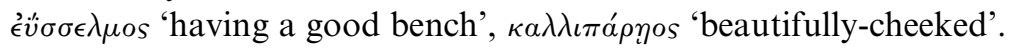
But when the noun specified by them is omitted they acquire the

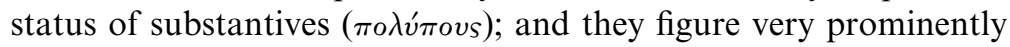
among Greek PNs: Hom. Па́трок入оs 'having fame descending from

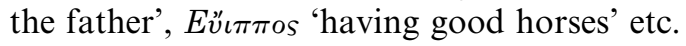

The FM can be constituted by either a noun ( $\rho \circ \delta \circ \delta \alpha ́ \kappa \tau v \lambda o s$ 'rosyfingered'), an adjective ( $\pi \circ \lambda \dot{v} \mu \eta \tau \iota s$ 'of many counsels'), a numeral

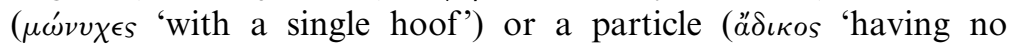
justice', 'unjust'). As mentioned above, the syntactic relation between FM and SM is usually of determinative type and the whole compound is exocentric.

${ }^{8}$ See also the discussion in Uhlich 1993: 78f., 90ff. who establishes a category 'Prädikativdvandva', distinct from exocentric dvandvas (114f.), and cf. also section 1.7 of Sadovski's contribution in this volume ('dvandva-complexives'). 


\subsubsection{Endocentric DCs}

A similar structure, but with very different morphosyntactic properties, is found in what are traditionally called 'determinative compounds': here also the relationship between the FM and the SM is that of modifier to head, and the FM can be seen as a modification of the main idea expressed by the SM (e.g. in oivó $\pi \epsilon \delta o \nu$ 'vineyard'). The FM can be represented by a substantive ('dependent' compounds or

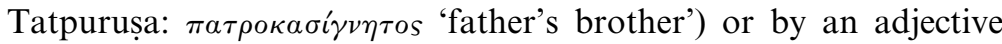


Cretans'). ${ }^{9}$ Although this type is the most productive in many languages, it seems only at its starting point in IE languages which are attested early. This is clear first of all from the paucity of examples, especially in early Greek. Also, a disproportionately large number of DCs seem to derive from juxtaposed syntagmatic expressions > univerbations; this is true in particular for the oldest looking ones and, despite the caveat expressed above, it is questionable whether stem composition was prototypical for this type of compound even in Proto-Greek (but cf. $\delta a ́ \pi \epsilon \delta o v$, see section 5.4.).

In early Greek, this can be illustrated by pointing to compounds such as $\delta \epsilon \sigma-\pi o ́ \tau \eta s$ 'house[gen. ]-master' or $\pi o ́ \delta a \rho \gamma o s$, Myc. po-da-ko 'foot-white' or 'foot-swift', originally derived from a syntagm $\pi \delta^{\prime} \delta$ '

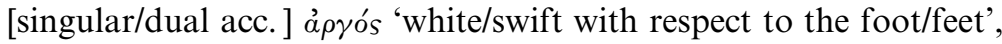

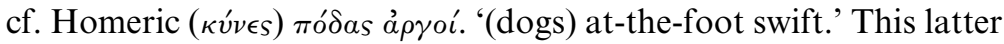
type is always derived from the juxtaposition of an accusative of respect and an adjective, or by the reinterpretation of a B, as in



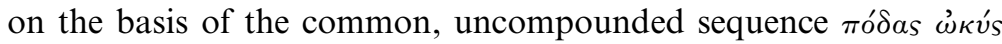
with practically identical meaning. Therefore, it must not be considered original: Greek, at an early stage, seems to have had 'true' adjectival $\mathrm{DCs}^{10}$ only to a very limited extent. Given that this type seems relatively recent, the Myc. evidence will be of particular relevance and the point will be taken up again in section 5.4.

9 This is used by Sanskrit grammarians for endocentric DCs only, but, following on from the brief discussion above can equally be applied to Bs, cf. MacDonell $1916^{3}$ : 276f. and Uhlich 1993: 97f.

${ }^{10}$ This is attested in the so-called type Armstrong, on which see Uhlich 1993: 101ff. 


\subsection{Governing compounds (Rektionskomposita)}

\subsubsection{Verbal governing compounds}

This productive group includes all those compounds showing a verbal root or stem in one of the members. ${ }^{11}$ The other member is usually a noun, which can acquire a number of functions; typically, though, it serves as the object of the verbal root or, in passive compounds, as the agent. The meaning is similar to that expressed by the participle of the same root (Risch 1974: 190). Sub-divisions of this type are necessary, since the verbal part can occur in the FM or in the SM, and can take several different morphological shapes. Verbal FMs appear in the following types:

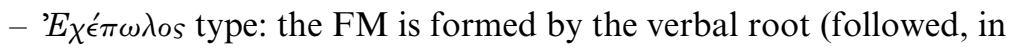
the case of thematic verbs, by the thematic vowel $-\epsilon-)$. The relationship between the members is normally verb-object:

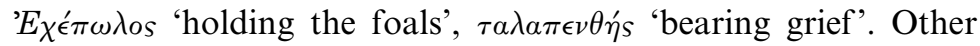
relationships do occur but are rare ( $\lambda \epsilon \chi \epsilon \pi \circ$ in $\eta$ 'lying in the grass'). These compounds have usually adjectival function, and when nominalised often function as PNs. In the early literature, the FM was interpreted as an original imperative, but Schwyzer 1939: 445 pointed out that the connection with imperatives is secondary.

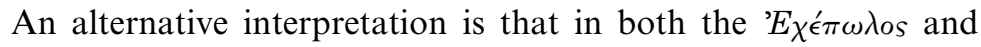
$\tau \epsilon \rho \psi$ i $^{\prime} \mu \beta \rho \tau$ os type below the FM is in origin a third person singular, though some authors retain the old interpretation (cf. Frei-Lüthy 1978: 23). ${ }^{12}$


member consists of verbal root $+-\tau \iota^{-} /-\sigma \iota^{-}$as shown by the example, meaning 'gladdening mortals'. Whatever their ultimate origin may be, ${ }^{13}$ as Schindler (1997) has pointed out, the synchro-

\footnotetext{
11 A subdivision of Sanskrit 'determinative' compounds in Wackernagel $\mathrm{AiGr}$ II, 1: 174.

${ }^{12}$ In favour of a third person singular is the interpretation of Benveniste 1967:

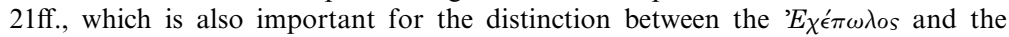

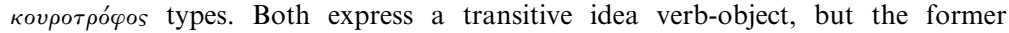
represents 'un présent intemporel de description' and the latter 'un présent actuel

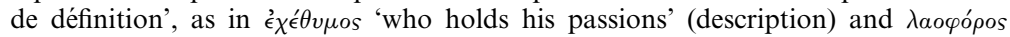
'which carries the people' (said of a wheel: definition).

${ }^{13}$ Schindler (oral communication) reasoned, with some considerable arguments,
} 


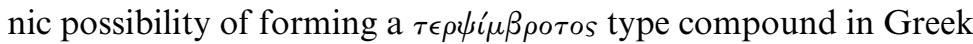
depends on the existence of a sigmatic verbal form (aorists/ futures). This means that such compounds could have been felt to be derived from the corresponding verbal form.

- Mixed types: formations of difficult interpretation that might have arisen as artificial hybrid forms (e.g. $\varphi v \gamma o \pi \tau o ́ \lambda \epsilon \mu o s$, with o in place of $\epsilon$ ) or might have been equated to VGCs. For example,

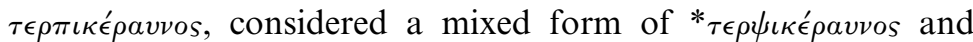
${ }^{*} \tau \epsilon \pi \epsilon \kappa \epsilon$ évvos by Risch 1974: 216, might actually be a B with a Caland-FM. This type is, so far, not attested in Myc.

Compounds with verbal SM can be distinguished according to the following categories:

- SM a verbal noun in the o-grade if possible (otherwise the

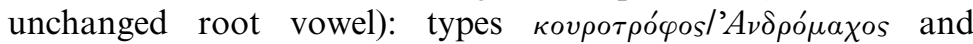

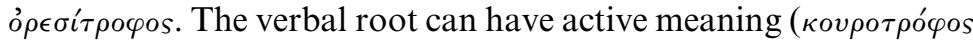


'mountain-bred': accent on FM). This is valid on a descriptive level: the passive meaning is in fact a relatively late Greek innovation, not entirely achieved in Homer. These compounds are initially Bs $(\pi \circ \lambda v ́ \varphi \rho \rho \beta s$ 'bountiful' < $<\circ \rho \beta \eta$; note the recessive accent typical for this class of compounds), but some could be interpreted as passives (e.g. ó $\rho \epsilon \sigma^{\prime} \tau \rho o \varphi o s$ 'having one's $\tau \rho \circ \varphi \eta^{\prime}$ in the mountains' $>$ 'reared on the mountains'), thus paving the way for the subsequent full-scale creation of a passive type (Risch 1974: 218).

- SM a verbal root, ${ }^{14}$ type $\beta$ ov $\lambda \lambda \eta^{\prime} \xi$ 'ox-beating', 'ox-goad'. The type is unproductive from Homer onward and many words of this class have been substantivised.

- SM an agent noun: type $\pi v \lambda \alpha ́ \rho \tau \eta s$ 'gate-keeper'.

- SM a participle, either active or middle: types 'I $\varphi$ ¿ $\alpha$ ' $\mu a s$ 'he who


gods'. This type is particularly prominent in PNs; indeed in

that these contain ready-made verbal abstract nouns and that the whole class thus ultimately represents a subsection of the Bs. By way of contrast, Dunkel 1992 (with many references to earlier literature on the subject) and 1999: $49 \mathrm{n} .8$ sees original si-



${ }_{14}$ On the morphosyntactic analysis of the SM see Scarlata 1999. 
Homer, these compounds occur with a nominal stem form as first members only as PNs. Univerbations such as $\pi \alpha \sigma \iota \mu$ '́ care to all' are found; the appellative type or $\pi \circ \nu \tau o \pi \circ \rho \epsilon v^{\prime} \omega \nu$ 'travelling on the sea' also occurs but is clearly secondarily derived

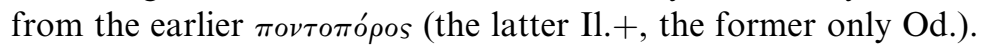
The appellative type $\pi о \nu \tau o \mu \epsilon \delta \omega \nu$ 'ruling the sea', ${ }^{15}$ not based on an o-grade VGC, is strictly post-Homeric (but $\Lambda$ aopé $\delta \omega \nu$ as PN already in Homer).


wrought'.

The principal problem presented by this category as a whole is the difficulty in determining, from a descriptive point of view, whether a verbal SM is still felt to be connected to the verbal root or is independent from it, as illustrated by ó $\rho \epsilon \sigma_{i}^{\prime} \rho \circ \varphi \circ$.

\subsubsection{Prepositional compounds}

In the so-called prepositional governing compounds (PGCs) the


'which is in heaven': 'heavenly'. ${ }^{16}$ Formal overlap with Bs is frequent: in 'є $\varphi v \delta \rho o s$ 'rainy' (a B) the preposition does not govern the following noun as is the case in "'́pa入os 'being at/by the sea'. Some words can be formally attributed to both categories: Risch

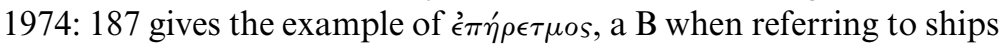
'equipped with oars' and a PGC when referring to men '(sitting) at the oars'. Confusion with DCs is also possible: cf. the case of

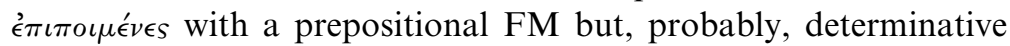



There is obviously a manifest weakness in the traditional classification. To have to classify $\epsilon^{\prime} \pi \eta^{\prime} \rho \epsilon \tau \mu o s$ under two completely different headings is hardly satisfactory. While it is also clear that the oars are in a different relationship to the rowers than they are to the ship, prototypically they may be united as 'oars (are) at X', i.e. 'having oars at (it/them)'. There may thus be reason to rethink the entire classification though this lies outside the scope of this survey.

15 First attested as $\pi о \nu \tau о \mu \epsilon \delta о \iota \sigma \alpha$ on a Corinthian krater, ca. 570 B.C, cf. Wachter 1990.

${ }^{16}$ For Sanskrit, cf. Wackernagel AiGr II,1: 308-313 who, rightly, classifies these compounds as exocentric.

17 See further Uhlich 1993: 97. 


\subsection{Further remarks}

Finally, three further remarks on NC in Greek:

- Three-member compounds are more recent creations and are peculiar to poetic, mostly comic, language (cf. Debrunner, 1917: 207). For those found in Homer one of the members is a


is found in Myc. as well.

- According to the standard view, all primary compounds are nominal in Greek (nouns, adjectives or participles). The frequent

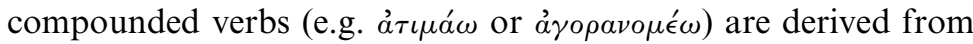


later stage of the language. But on the new tablets from Thebes (preliminary reading), Myc. now reveals some troublesome evidence. It would be easy enough to dismiss $t u$-wo-te-to on TH Fq 121 as either a scriptio continua for $\theta$ v́os $\theta$ '́ंтo 'a sacrifice was made' or as a haplography for *tu-wo-te-te-to from a hypothetical verb * $\theta v o \theta \epsilon \tau \epsilon \epsilon$ (cf. $\omega \mu \circ \theta \epsilon \tau \epsilon \epsilon \omega$ 'place the raw pieces [on the altar]' and cf. po-ne-to for the inflection, see Killen 1999) which, in turn, would be a secondary derivative from ${ }^{*} \theta v o ́ \theta \epsilon \tau o s$, were it not for the enigmatic but parallel and seemingly similarly formed $o$-je-ke-te-to on $\mathrm{TH} \mathrm{Fq} 130 .{ }^{18}$ The whole problem needs further evaluation when the Thebes tablets are finally published in an authoritative fashion.

- The compositional category of Dvandva or 'copulative' compounds is widely attested in Sanskrit and is also present in Greek (type $\left.v v \chi \theta \eta_{\mu}^{\prime} \epsilon \rho o v\right)$ but, so far, absent from Myc. It would be interesting to know whether this absence is due to pure chance or whether Dvandvas developed at a late stage in Greek. Myc. evidence can in fact change our views on the age of some phenomena, as will be demonstrated below for 'iterative' compounds.

${ }^{18}$ Chadwick 1996-1997: 293ff., apparently followed by Melena 2001: 49f., interprets these not as compounds but as aorist passive forms. While this is more satisfactory from the point of view of word formation, the medio-passive ending is obviously extremely difficult. 


\section{The Myc. EVIDENCE}

\subsection{Myc. Bahuvrīhis}

Ca. 400 nominal compounds are so far attested in Myc.; out of these, between $20 \%$ and $25 \%$ are possessive compounds (approximately 85 forms, including some of disputed interpretation). More than two thirds of these are PNs. The remainder is divided between adjectives (ca. 14 forms), substantives (ca. 7 forms) and two toponyms. This distribution is at odds with later Greek where large number of appellative compounds are attested in poetry or literature; but bureaucratic records are more likely to register PNs than adjectives or substantives (this latter category being often represented by ideograms or abbreviations).

The examination of Bahuvrīhi PNs reveals an interesting correspondence with later Greek, in both compositional patterns and members involved. Examples of good later Greek antecedents are $e$ -






210). A puzzling correspondence is that between $a_{3}$-ki-po-de (dative), which seems to be a toponym in Myc., and aijímovs 'goat-footed', epithet of Pan. ${ }^{19}$

Bs with adjectival FM are common. Many examples with $\epsilon \dot{v}$ occur (beside those mentioned above, cf. the anthroponyms $e-u-p o-$

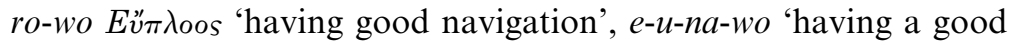
ship', e-u-me-ta 'having good $\mu \hat{\eta} \tau \iota s)^{20}$ and for $\epsilon \hat{v} \rho v$ - cf. e-u-ru-po-to-


oikos'. Good B patterns can be observed in other PNs: o-ku-na-wo


coloured eyes', with SM from $* h_{3} e k^{w}$-, found also in other compounds: cf. the ox-name wo-no-qo-so 'with wine-coloured eyes', and

19 The evidence (PY Mb 1397) is not helpful. The tablet consists of one line only, where $a_{3}-k i$-po-de is followed by $* 146$ [. Other tablets of the series, when complete, seem to contain both anthroponyms and toponyms. For the shape of the SM see section 6.3.

${ }^{20}$ Cf. $D E G$ s.v. $\mu \hat{\eta} \tau \iota s$ for $-\mu \eta \tau \eta s$ from $\mu \hat{\eta} \tau \iota s$. 
the PN ti-ri-jo-qa and $a_{3}$-ti-jo-qo). ${ }^{21}$ The anthroponym re-u-ko-ro-o$p u_{2}-r u$ might be interpreted as 'having white eye-brows' ( $\lambda \epsilon v \kappa o ́ s$ and o $\varphi \rho \hat{v} s)$, but the presence of ro still militates against this solution. ${ }^{22}$ Phonetic problems concern also the interpretation of the name $o-t u$ wo-we '?having straight ears' (if from óp $\theta$ 's and oùs).

For nominal FM, cf. wo-no-qo-so (see above), ke-ro-ke-re-we-o

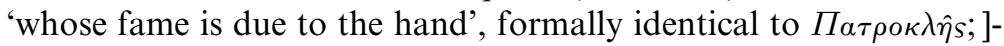
mo-ke-re-we-i, probably with a FM $\alpha \rho \mu o-$ or $\delta \alpha \mu o-$.

Other compounds may be reversed Bs, cf. a-mo-to-wo ?'having a


from $\theta \dot{\epsilon} \omega$ 'to run' is more likely. The distinction between the two types is often very hard to determine: the anthroponym $a-k a-t o-w a$, probably corresponding to Hom. ' $A \lambda_{\kappa} \alpha \theta_{o o s}$, is a useful example; it is most naturally interpreted as 'running to help' (a VGC) but von Kamptz 1982: $74^{23}$ interprets it as 'having fast $\alpha{ }^{\lambda} \kappa \eta^{\prime}$ ' (B). This is also

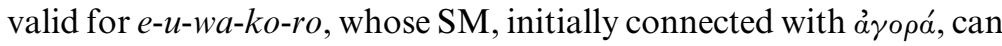
be understood as derived from áyopáopaı (Risch 1974: 210). Compounds in -voos can be interpreted at times as Bs (as perhaps wi-pi-no-o 'having his vóos through the strength'?), at times as VGCs (cf. Hom.

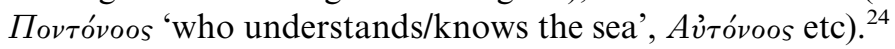

Theoretical overlap with a verbal type is also to be found in compounds with SM -me-de: since the Myc. spelling does not allow us to ascertain whether the $e$ is short or long, the root can belong to either $\mu \hat{\eta} \delta o s$ or $\mu \epsilon ́ \delta \rho \mu a / \mu \delta^{\prime} \delta \mu \alpha \iota$. Some compounds reveal their nature by comparison with Greek: for instance, a-no-me-de, inter-

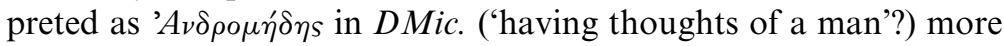
probably corresponds to ' $A \nu \delta \rho{ }^{\prime} \epsilon \in \delta \eta s$, attested much earlier than $' A \nu \delta \rho \circ \mu \eta^{\prime} \eta{ }^{2},{ }^{25}$ and is possibly a VGC. Other forms are probably Bs: pe-ri-me-de, e-ti-me-de, a-pi-me-de.

${ }^{21}$ For wo-no-qo-so cf. Hom. Il. 13.703: ßó 21.144 Oivo\%. According to Ruijgh 1967: 255 n. 106, a fourth form, mi-jo-qa, might show a FM connected with $\mu$ « pós ('aux petits yeux').

${ }^{22}$ For the interpretation of the form see DMic. s.v. The hypothesis of a scribal error is possible, of course; but caution is necessary, cf. Risch 1983, in particular p. 382 .

${ }^{23}$ This name is also read as $<\dot{\alpha} \gamma \alpha \theta o^{-}$, cf. Landau 1958: 17.

${ }^{24} \mathrm{Or}<*$ *nes- 'to return'; wi-pi-no-o has been interpreted as 'he who returns through his strength' by Thompson 1999: 341 .

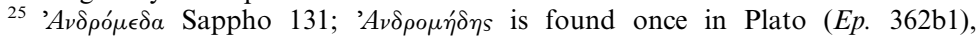
otherwise forms in $-\mu \eta \dot{\eta} \eta s$ are found from the third century B.C. onwards. 
Myc. attests case forms as FM, a feature observable in Homeric names (Risch 1974: 219). The most clear-cut attestation is na-u-si-


$m e-n e^{26}$ and possibly also $a-r e-i-z e-w e-i$ show a FM which is



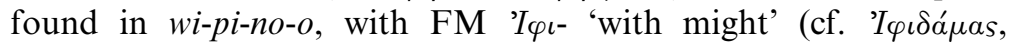

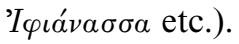

Appellative, adjectival Bs can be compounded with a privative $\dot{\alpha}(\nu)-$, as in $a$-ko-to-no 'without land' (as opposed to ko-to-no-o-ko); $a-k a-r a-n o$ 'without head' (referring to a table); $a-n a-p u-k e$ 'without head-bands'; a-no-wela-no-wo-to 'without handles', ${ }^{27}$ and probably a-no-no 'having no $o$-no' and opposed to $o$-na-to 'profit' ${ }^{28}$ All these forms correspond to Hom. type a $\kappa \tau \tau \eta \dot{\mu} \mu \omega \nu$ 'without property'.

Among forms with a numeral as FM cf. ti-ri-jo-welti-ri-o-we 'with three handles'; e-ne-wo-pe-za 'nine-footed' (referring to a table); qeto-ro-we 'with four handles'. Compounds with SM indicating a part of the body are common in Greek, see the table of SMs in Risch 1974: 183, where 13 out of 42 are of this type. In Myc., cf. also qo-u$k a-r a$, designating the typical bull-headed rhyton, the pair re-u-ko$n u$-kalpo-ki-ro-nu-ka and, among substantives, po-ru-po-de 'octopus'. All the adjectives qualify furniture or cloths: the SM is not really indicating a part of the human body (as so frequently in


employed in a metaphorical way. po-ki-ro-nu-ka and re-u-ko-nu-ka are clear examples of this usage: the pair refer to wool decorations attached to cloth and not to real ö $v v \chi \epsilon S^{\prime}$ 'nails' (cf. the concrete use of the word in the Homeric epithet of horses, $\left.\mu \omega^{\prime} v v \chi \in s\right)$ and may mean 'with coloured tassels or speckles' and 'with white tassels or speckles' respectively. NC (particularly those compounds traditionally considered typical of poetic style) was thus not limited to poetry, but was a feature of a lower level of language as well.

The structure of compounds can vary: qe-to-ro-po-pi, instrumental of a noun indicating 'quadrupeds', po-ru-po-de 'octopus', ti-ri-po-de

26 The form alternates with a-re-me-ne.

27 Probably */án-ous-es-/ and */an-oúsn-tos/.

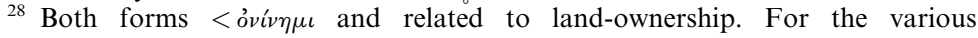
interpretations of $o$-na and $o$-na-to see DMic. sq.vv. 


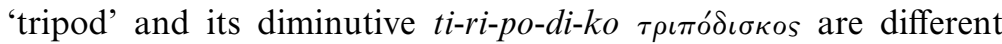
from e-ne-wo-pe-za 'nine-footer', we-pe-za 'six-footer'. The most sophisticated form appears to be se-re-mo-ka-ra-a-pi 'siren-headed', a noun referring to the ornamental motive of a piece of furniture; but this may be a mere juxtaposition, the FM being a genitive singular, dual or plural. ${ }^{29}$

\section{2. $M y c . V G C s$}

\subsubsection{With verbal FM}

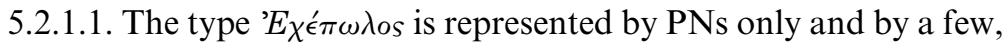
not always unambiguous examples (around 6). Five of them have a

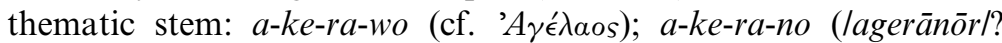
lagelānōr/?); a-ke-wa-ta (lage-wastās/? cf. the probable Greek cor-


stem is possibly found in te-ra-u-re-o, if =/tel-auleos/, with FM from the root $\tau \lambda \alpha$ - 'to hold' but the interpretation, especially of the SM, is very uncertain. ${ }^{31}$ Given the evidence of later Greek, one might expect a FM tlā- or tala-; but it is true that from a root $* t_{e} \operatorname{lh}_{2}{ }^{32}$ /telaulos/ is perfectly possible. This interpretation might be supported by te-ra-pe-te, if comparable to $\tau \alpha \lambda \alpha \pi \epsilon \nu \theta \eta^{\prime} s$ (Ruijgh 1967: 378); but it must be noted that other interpretations regard it as an agent noun (Risch 1987: 286). In this group all the SMs function as the object of the verbal FM.

5.2.1.2. The type $\tau \epsilon \rho \psi^{\prime} i_{\mu} \beta \rho о \tau o s$ is constituted only by PNs, including a theonym. A good Greek form is ma-na-si-we-ko 'he who is

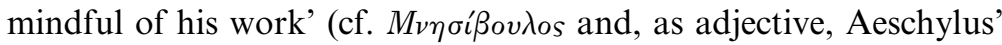
$\left.\mu \nu \eta \sigma \iota \pi \eta^{\prime} \mu \omega \nu\right)$. The pair ke-sa-da-ralke-sa-do-ro corresponds to Greek $K \alpha \sigma \sigma \alpha \dot{\nu} \delta \rho \alpha, K \alpha \dot{\sigma} \sigma \alpha \nu \delta \rho o s$ and may show *kasti> kass as FM (from

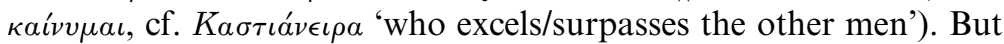
the alternating vocalism of FM is better interpreted as a sign of

${ }^{29}$ If so, the compound is better considered a DC. The graphic division in one case may be attributed to a tendency of the scribe and not to its status as a juxtaposition, cf. 6.2.

\footnotetext{
${ }^{30} \mathrm{IG} \mathrm{II}^{2} 1609$ (336 B.C.).

31 Petruševski 1965: 125. Ruijgh 1967: 378 reads /telhaulēs/ 'qui porte du bois'.

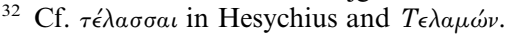


non-Greek etymology: both forms could ultimately represent preGreek names borrowed by Greek already at the Myc. stage and reinterpreted as containing $-\alpha \nu \delta \rho$ - as $\mathrm{SM} .{ }^{33} q i-s i-a-k o$ might corre-

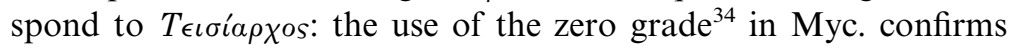
that FMs from aorist stems are secondary (Risch 1974: 192).

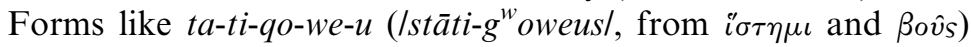



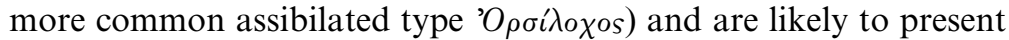
(rural?) archaisms. Likewise, it is not surprising that even in the Ionic-based Homeric text PNs can preserve a conservative pronunciation, ${ }^{35}$ which might but need not reflect a different geographical provenance (i.e. north-Aeolic). As Frei-Lüthy 1978: 15 notes, this supports the archaic nature of this type. It must be noted, however, that the presence of only PNs is not surprising, given that, owing to its nature, the Myc. evidence mostly consists of anthroponyms; the conclusion that this type originated in PNs is unwarranted.

The correspondence between the theonym e-ne-si-da-o-ne and



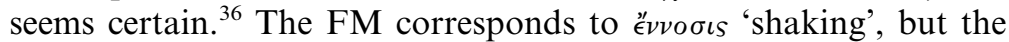
alternation elo is unexplained. There is no Greek verb corresponding to this FM, while the nomen actionis seems to be very old and on its way out in classical Greek ( $D E G$ s.v.). A solution to the problem might be that confusion between FM derived from third person singular forms (or whatever the origin of the $\tau \epsilon \rho \psi_{i}^{\prime} \mu \beta \rho о \tau o s$ type may be) and nomina actionis is already in progress at the Myc. stage. But ultimately a pre-Greek origin cannot be ruled out.

\subsubsection{With verbal SM}

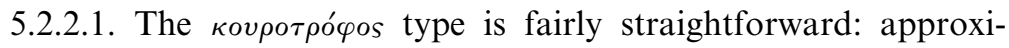
mately 40 forms are attested, of which only 4 are uncertain; most of them are substantives, usually indicating professions or functions:

33 See first Sommer 1948: 189-90, considered by Risch 1974: 227 n.42 and von Kamptz 1982: 95-6. It applies to 'A $A \epsilon^{\prime} \xi \alpha \nu \delta \rho o s$ (a-re-ka-sa-do-ro) as well.

34 Assuming that the $i$ is short, if $\tau^{\prime} \nu \omega$ (with long $i$ ) is the result of compensatory lengthening $\left(\tau^{\prime} \nu-F \omega\right)$. The original root grade is probably zero, $\tau^{\prime} i v \omega$ being an

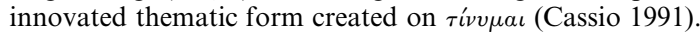



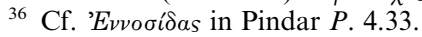


-wo-ko /worgos/: to-ko-so-wo-ko 'bow-worker'; ku-ru-so-wo-ko

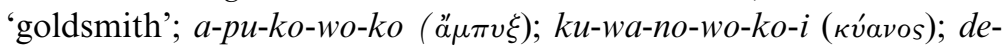

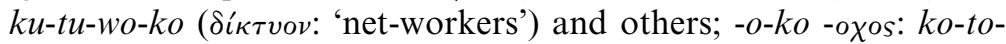
no-o-ko 'land-owner'; wa-tu-o-ko 'city-holder' (anthroponym, cf.

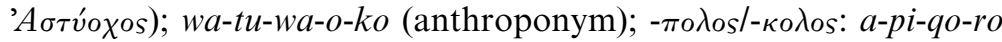

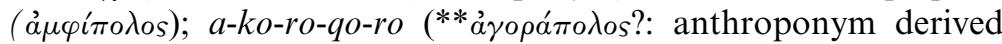
from a title?), ${ }^{37}$ qo-u-ko-ro (ßоvкódos) and the obscure sa-ri-qo-ro, ${ }^{38}$


te-u-ta-ra-ko-ro ${ }^{40}$ (or from $\left.a \gamma \in i \rho \omega\right)$ and the much-disputed da-moko-ro. ${ }^{41}$

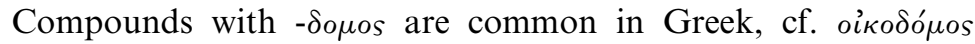
'house-builder'. Myc. forms include: na-u-do-mo 'ship-builder' and $e$-te-do-mo, probably from $\stackrel{\prime}{\prime} \nu \tau \epsilon \alpha^{\prime}$ 'arms', 'tools'. If this interpretation is correct, we would have two compounds with different forms of the suffix: $-\epsilon \sigma$ - in $e$-te-do-mo and -o $\sigma$ - in $e$-to-wo-ko, or indeed the latter form may show the substitution of the suffix with thematic-o-. All three options are found in later Greek (cf. $\tau \epsilon \lambda \epsilon \sigma \varphi o ́ \rho o s, \theta v o \sigma \kappa o ́ o s$, $\sigma \kappa v \tau o \tau o ́ p o s)$, although the common stem for compounds with $\stackrel{\epsilon}{\nu \tau \epsilon a}$ is $\epsilon^{\prime} \nu \tau \epsilon \sigma^{-}{ }^{42}$



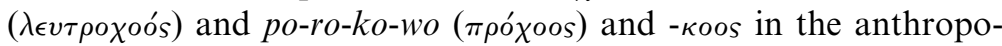
nym $p u-k o-w o$, if it is to be interpreted as 'watcher of the sacred

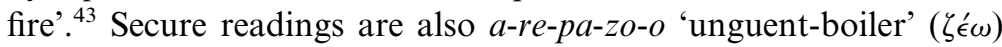


$\mathrm{SM}$ may be found in $a$-si-to-po-qo though the meaning is uncertain.

37 But Killen 1992b: 111 notes that while 'there are several examples in the records of PNs based on trade-names, (po-me . . . etc.) [ . . . ] there are no certain instances of PNs based on official titles'.

${ }^{38}$ FM rapís according to Lejeune Mém. I, 294.

39 New reading for earlier re-qo-na-to-mo; /hikk ${ }^{w}$ on/ a-to-mo, cf. e-qe-(a)-o a-to-mo? Another obscure form is $i$-za-a-to-mo-i, which probably does not contain - $\tau$ oros (*a $\rho \theta \mu$ ós, according to Docs. ${ }^{2} 549$ ).

40 FM /teutl-/ 'beetroot' ('beetroot-collector': Docs. 247) or /teuthr/ 'crimson'?

${ }^{41}$ An interpretation from á $\gamma \epsilon i \rho \omega$ is difficult; Myc. seems to behave according to Wackernagel's Law (4.1.) and therefore one should expect an outcome **da-ma-ko-ro in the Kompositionsfuge.

${ }^{42} \mathrm{Cf}$. section 6.3. Other interpretations: $e$-to $\ddot{\epsilon}^{\prime} \nu \tau o s$ or the name of an unidentified building, see DMic. s.v.

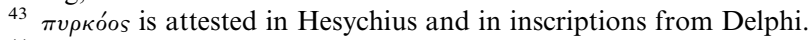


influenced by compounds of кó $\tau \omega \omega$. 
The interpretation of the cult category of di-pte-ra-po-ro is equally uncertain: interpreted at times as /dip ${ }^{h} t^{h} e r a-p^{h}$ oroil 'leather-carriers/ wearers' (for FM, cf. te-o-po-ri-ja), at times as /dip ${ }^{h} t^{h}$ era-pōloil 'leather-sellers', its actual meaning is unknown. But ka-ra-wi-po-ro (a religious officer) is clearly /klāwi-phoros/ 'key-bearer' and it has


priestess at Messene and Lagina respectively.


functioning as an object; compounds like a-pi-qo-ro 'attendants', cf. $\alpha \mu \varphi i ́ \pi$ òos obviously do not belong here as their first member is not a noun and, arguably, they are not nominal compounds but derived from compounded verbs. In later Greek, forms with


the road'.

5.2.2.2. The status of the ófбít $\rho \circ \varphi$ os type is much more uncertain. No secure examples with a nominal FM are attested. A small number of compounds (at best 6 forms) show passive meaning, ka-si-ko-no (?**aбírovos 'born together'), pe-ra-qo-no, perhaps

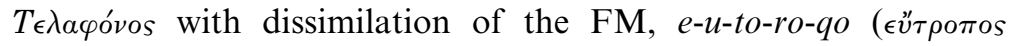
'versatile', anthroponym); o-pi-ro-qo and pe-ri-ro-qo 'left-over';

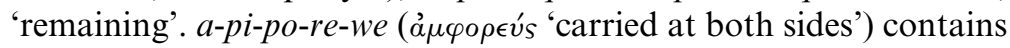
a different suffix (also classifiable in the following section). Again, these forms may be derivatives of compounded verbs.

5.2.2.3. Compounds with an agent noun as SM form the most prolific category $(40+$ forms $)$, confirming the great productivity of nomina agentis observable in simplicia (see Leukart 1994). Both substantives and anthroponyms are found. Antecedents of historical Greek forms are: $k u$-na-ke-ta-i 'hunter' (dative/locative plural), ra-

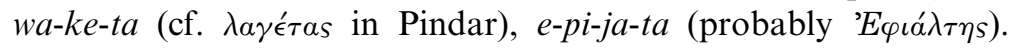
Particularly noticeable are compounds with SM $\delta a ́ \mu \alpha \rho$, which alternates with a form in $u$ : me-ri-da-ma-telme-ri-du-ma-te. This seems to reveal a non-Greek origin of the word, ${ }^{45}$ traditionally believed to be a nomen agentis from the root *demh $h_{x}$ 'to build'

${ }^{45}$ A hypothesis of Chantraine's, later reproposed by Ruijgh 1987 (cf. in particular p. 302). 
(Lejeune 1957). But as Leukart apud Ruijgh 1987: 322 remarks, a pre-Greek origin does not exclude an Indo-European etymology. The meaning of the Myc. form should be 'supervisor': in this case 'supervisors of honey' (with cultic implications?). In later Greek $\delta \alpha$ ' $\alpha \rho$ means 'spouse', a specialisation, according to Ruijgh, of the original meaning 'qui a soin de la maison'. Another form whose SM is difficult to determine is $o-w i-d e-t a-i$, probably indicating cult functionaries: 'sheep-flayers' (Docs. ${ }^{2} 458$ : $\left.\delta \epsilon ́ \rho \omega\right)$ or 'those who bind the victim for the sacrifice' (Ruijgh 1967: 265: $\delta \epsilon ́ \omega)$. The same can be said for $a_{3}-k i$-pa-ta 'goat-herd' whose SM is disputed. ${ }^{46}$

Interpretative problems concern the common SM -qo-ta, which is alternatively read as $-\varphi \circ \nu \tau \eta s,-\varphi \circ \iota \tau \eta s$ or $-\beta o \tau \eta s /-\beta \omega \tau \eta s$. Sometimes, a

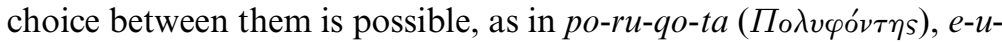

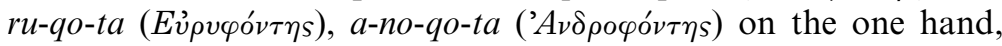



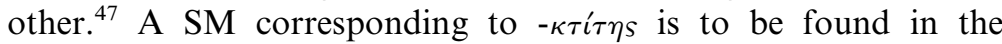
substantive $m e-t a-k i-t i-t a^{48}$.

5.2.2.4. Compounds with a verbal adjective as SM are mostly represented by adjectives, cf. ka-ko-de-ta 'bronze-bound' (SM

46 Landau 1958: 205 and 274, followed by others, sees in it a form of $\pi \alpha \tau \tau^{\prime} о \mu \alpha \iota$ (Lat. pasco) and quotes Cretan $\pi \alpha ́ \sigma \tau \alpha s$ (Leg. Gort.), which is otherwise

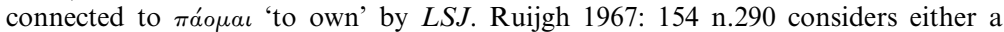
SM from $\pi \alpha \pi \tau \alpha i v \omega$ (Cypriot $\pi \alpha ́ \tau \alpha \mu \iota)$ 'to watch', with a meaning 'goat-watcher',

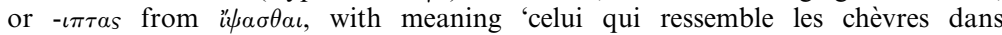
l'enclos'. This latter interpretation was proposed by Heubeck 1963: 20 in order to avoid assuming the presence of a compositional vowel (see 6.3.) but is semantically unsatisfactory as iభá $\mu \eta \nu$ in Homer means 'to oppress', 'to hurt' rather than 'to gather'.

47 The occurrence of two different spellings of what seems to be the same word, $q o$ - $u$-qo-ta and qo-qo-ta, might be ascribed to a dissimilation or to the use of two different stems of $\beta o v \hat{s}$, cf. the Homeric accusative $\beta \hat{\omega} v$ (Myc. acc.pl. qo-o) which might influence the formation of compounds. The forms with the second labiovelar preserved certainly contrast with the dissimilated qo-u-ko-ro. Lejeune 1972: 45 assumes that the labiovelar is preserved in qo-u-qo-ta in analogy to ßó $\sigma \kappa \omega$. One could object that a similar analogy should have worked with words with SM -qo-ro; nonetheless, qo-u-ko-ro is dissimilated.

${ }^{48}$ Meaning perhaps 'new settlers' Docs. ${ }^{2}$ 431, or 'transported population', see Palmer 1963: 90. 
from $\left.\delta \epsilon^{\prime} \omega\right) .{ }^{49} a$-na-mo-to, qualifying $i$-qi-ja, formed by negative $\grave{\alpha} \nu$ - and SM derived from $\alpha \rho \mu o ́ \zeta \omega$ probably means 'not put together' (Docs. $\left.{ }^{2} 362\right) .{ }^{50} \mathrm{Cf}$. also a-pi-qo-to, referred to to-pe-za, compounded with $\alpha \mu \varphi i^{\prime}$ and the verbal adjective in the zero grade from $\beta \alpha i v \omega * g^{w} m_{o}$ tós. It seems to indicate a table 'with a rim around' (Docs. $\left.{ }^{2} 499\right)$, cf.

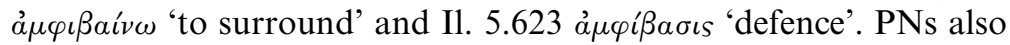
occur, cf. the striking $a$-qi-ti-ta, corresponding to Hom. á $\varphi$ A 'imperishable'.

The etymology of $a$-na-to is more obscure: if the SM is from

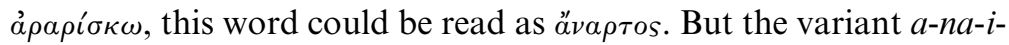
ta seems to indicate a root with - $i-$ : if so, it is probably to be connected with $a$-ja-me-na 'inlaid' (of which $a$-na-to should be the

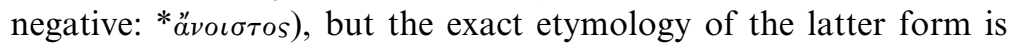
disputed.

Among the anthroponyms, $a$-ne-ra-to, if read as ** ${ }_{\alpha} \nu$-'́ $\rho \alpha \sigma \tau o s$ 'not loved' (Lejeune 1958: 203), would certainly have an odd meaning for

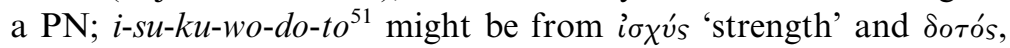
'provided with strength'. But the absence of $w$ in the Myc. form is surprising. ${ }^{52}$

5.2.2.5. Other compounds (mostly PNs) are formed with a verbal noun of the type ásxós (Risch 1974: 207d): cf. ka-ra-na-ko, from $\kappa \rho \eta ́ \nu \eta$ and á $\rho \chi o^{\prime}$ (a functionary possibly similar to the Latin curator aquarum, see DMic. s.v.); the anthroponym po-ma-ko, considered to be a compound of $\pi \circ \mu \eta \eta^{\prime}$ and -ayos or - $\alpha \rho \chi o s$ 'leader of the flock'; ruko-wo-ro (anthroponym), with SM from o $\rho \alpha \omega^{\prime}$ ?; the interpretation of $t a-t a-q e-u$ as an anthroponym derived from $\sigma \tau \rho a ́ \tau \alpha \rho \chi o s$ is difficult and unlikely.

The feminine name te-o-do-ra is not only identical to a Greek form, but also testifies to the derivation of feminine forms from masculine ones ( $\Theta \epsilon o ́ \delta \omega \rho o s$ is the starting point here) being as old as Myc. $^{53}$

49 Or two words, given the occurrence of $k a-k o$, de-de-me-no on PY Sa 794?

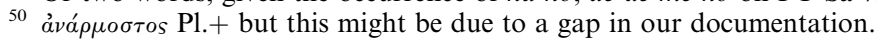

51 If not to be read as an adjective specifying oil (it is followed by OLE).

52 Chantraine DEG 472 believes that the $w$ found in some dialectal forms of i $\sigma \chi v^{\prime}$ is not original, but due to analogy with is: this could explain the absence in the Myc. form.

${ }^{53} \mathrm{Cf}$. also $a$ - $t i-k e-n e-j a$ and others. 
5.2.3. VGCs that do not belong to one of the previous categories include:

- compounds with FM $\varphi$ ido- (17, all anthroponyms such as pi-ro-pata-ra, $\left.\Phi_{\iota} \lambda_{o} \pi \alpha \dot{\tau} \rho \alpha\right)$. Originally a B 'she who has a loving father/father as a friend', then reanalysed as a VGC 'she who loves the father';

- compounds with verbal SM and adjectival suffix - $\eta s$, such as $p o-$ ro-e-ke. ${ }^{54}$ same uncertainty for pu-ko-so e-ke-e ( $\pi v \dot{\xi} \xi o s$ 'box-wood' and SM interpreted as $-\epsilon \chi \eta^{\prime} s,-\epsilon \gamma \chi \eta^{\prime} s$ or $\left.-\epsilon \rho \kappa \eta^{\prime}\right),{ }^{55} k e-r e-s i-j o$ we-ke (from /wergēs/ 'of Cretan workmanship/style': the type is attested

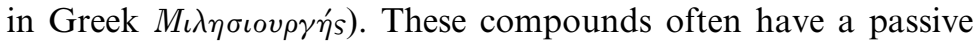
meaning; 56

- compounds containing a verbal root (noun): $k e-n i-q a\left(k^{h} e r-n i g^{w}-s\right.$, nom. sg. with 'dead' vowel $-a$; $\mathrm{cf}$. Hom. accusative $\chi \epsilon$ ' $\rho \nu \beta \alpha$, from $\chi \epsilon i \rho$ and root of $\nu i \zeta \omega$ : $\mathrm{cf}$. Risch 1974: 194) and ke-ni-qe-we (with - $\epsilon v s$ suffix);

- compounds with abstract noun: $a$-no-qa-si-ja, perhaps corres-

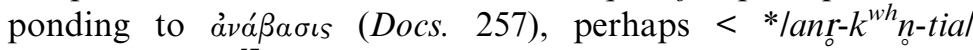
'manslaughter'; 57

- forms whose FM or SM seem verbal, but are difficult to interpret: thus the substantive $u$-wo-qe-we $e^{58}$ and also the anthroponym ${ }^{59} k e-$ $u$-po-da (the interpretation as a title 'libation pourer' ${ }^{\prime 6}$ from $* \hat{g}^{h} e u->\chi \chi^{\prime} \omega$ and $\sigma \pi o ́ v \delta \alpha s$ is unsatisfactory from a morphological point of view: one might expect **ke-we-po-da if the word

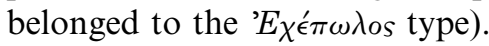

\subsection{Myc. prepositional compounds}

Myc. has a good number of forms that seem to contain a preposition as FM (around 37), but their interpretation as

54 Interpretation uncertain, cf. Docs. ${ }^{2}:$ 501, DMic. s.v.

55 For the presence of divider among the members of a real compound, cf. DMic. S.v.

${ }_{56}$ Cf. Bader 1965 for /-worgos/ and /-wergēs/ in Myc.

57 Mühlestein 1958: 225, followed by Killen 1992c: 380.

58 Probably SM lok $k^{w} \bar{w} e s /$ from ${ }^{*} h_{3} e k^{w}$-. FM $u$ is sometimes considered an equivalent of '́ti (cf. Morpurgo Davies 1971: 90, with scepticism) and the very existence of this preposition has been questioned. The whole compound could mean 'overseers'.

59 A name, not a title, as shown by Killen 1992 b.

${ }^{60}$ Palmer 1963: 303, followed by Ruijgh 1967: 262. 
PGCs, being based on the meaning, is often difficult to determine. Some words can be excluded on the basis of structure, for example those deriving from a verbal root provided with a preverb: o-pi-ro-

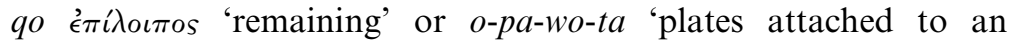
armour'.61

Among the forms of secure interpretation, many are compounded with epi or opi. Some of them define objects and can be used as substantives or adjectives: e-pi-ko-ru-si-jo/o-pi-ko-ru-sijo 'attached to the helmet'; e-pi-ki-to-ni-ja 'things attached to a tunic'; e-po-mi-ni-jo 'shoulder-pieces'; o-po-qo 'blinkers'; o-pi-kere-mi-ni-ja 'things behind a chair; back of the chair?'; o-pi-i-ja-pi (instr.) 'things connected to reins'; o-pi-de-so-mo 'things close to $\delta \epsilon \sigma \mu o i$. Others are occupational nouns: o-pi-te-u-ke-(e)-we 'supervisors of vessels'; o-pi-te-ke-u '?supervisor of the palace' (Ruijgh 1983: 397), or a misspelling for o-pi-te-u-ke-u; o-pi-tu-rajo 'porter'; o-pi-ko-wo '?those in charge of boys';62 o-pi-ka-pe-ewe, 'supervisors of diggers' (/skap ${ }^{h} e \bar{e} w e s /$, cf. $\left.\sigma \kappa \alpha \varphi \epsilon v_{s}\right)$ or 'supervisors of vessels' (from $\sigma \kappa a ́ \varphi o s ~ ' s h i p ') ; ~ e-p i-s u-k o$ 'supervisors of figs?'.63

The alternation between epi and opi in some forms and their use in similar contexts (as in o-pi-te-u-ke-e-we and e-pi-ka-pe-e-we) may imply comparability of meaning. In some circumstances, it may be that opi (continued by Greek adverbs such as ö $\pi \iota \epsilon \nu$ ) means 'back; behind' (o-pi-ke-re-mi-ni-ja?); but a closer specification of meaning is impossible and Morpurgo Davies (1983) has argued that both opi and epi are precursors of $\epsilon \pi i$. The cor-

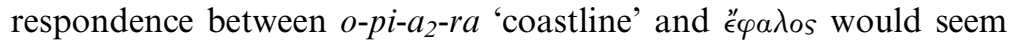
to confirm this.

Compounds with other prepositions are less numerous. For $\stackrel{\epsilon}{\nu} \mathrm{cf}$.

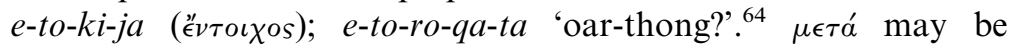

${ }^{61}$ SM probably from $\alpha \epsilon i \rho \omega$, with the meaning 'things which hang opi' and as such a verbal and not a prepositional compound: Morpurgo Davies 1983: 298.

${ }^{62}$ SM actually disputed: see 5.2.2.1.

${ }^{63}$ A FM бөิко is rejected by Palmer 1963: 438. It is possible from a linguistic point of view, but the meaning does not fit the context that implies AES and not figs. On the other hand, his counter-hypothesis is no more satisfactory: 'it may well be that the basic word is of Aegean origin, like "ँ $\rho \chi \eta$ ' (p.283).

${ }^{64}$ Palmer 1963: 421. 
attested in two anthroponyms: me-ta-ka-wa ${ }^{65}$ and me-to-qe-u (cf.


$n i$-jo, if it derives from the epithet of Poseidon $\epsilon \pi \iota \lambda i ́ \mu \nu \iota s$ (see DMic. s.v.).

\subsection{Myc. endocentric DCs}

These compounds are rare in Homer, but become a rather productive category in Attic, without acquiring the importance that is observable in Sanskrit DCs. The Myc. evidence, with its small number of entries $( \pm 47$, approximately $13 \%$, including those of difficult interpretation), matches the data in Homer. This category consists mainly of place names in Myc. (around half of the entire group) and these do not seem to have the structure of proper compounds. Cf. in this respect the pair pe-ra- $a_{3}-k o-r a-i-j a$ ('Further Province') and de-we-ro- $a_{3}-k o-r a-i-j a$ ('Hither Province'), where it is clear that the Greek adverbs $\delta \epsilon \hat{v} \rho o$ and $\pi \epsilon \rho a s$ form a unit with the following element, but are not really or at least not necessarily compounded with it. The same holds good for toponyms formed by two nouns, at times written with a word divider, as e-ra-po ri-me-ne lelap ${ }^{h}$ on limeneil, more likely than /elap ${ }^{h}$ olimeneil. Many later Greek



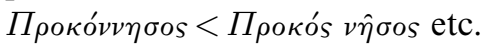

Both the morphology and the graphic realisation of Myc. forms reveal their status as original or actual juxtapositions, cf. ko-ro-jowo-wi-ja, whose apparent FM should be read as an independent genitive probably of $\chi \hat{\omega} \rho$ os (the apparent SM, frequent in toponyms, corresponds to Attic ópos 'boundary'); or te-mi-to-a-ke-e, whose apparent FM seems to be the genitive of $\theta \epsilon^{\prime} \mu s$; ${ }^{66}$ and ]-no-ka-ra-o-re, which might have кvvós as FM ('dog-head') and thus resemble Greek toponyms such as Kvvoбќ́ in the rendering of the Kompositionsfuge, very frequent among

${ }^{65}$ Interpretation uncertain; Ruijgh 1967: 255 n.106: from the expression $\mu \epsilon \tau \dot{\alpha}$

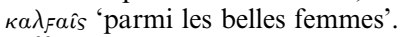

${ }^{66}$ Cf. among others Ruijgh 1967: 94.

${ }^{67}$ A fourth example may be added: ma-to-ro-pu-ro, where the FM possibly represents a genitive and not the outcome of a syllabic resonant, as one might expect in proper compounds such as qe-to-ro-po-pi. Morpurgo Davies 1968: 803 admits the possibility of a 'non-morphological vowel'. See also below section 6.3 . 
toponyms, ${ }^{68}$ and the occasional writing of a form as two separate words, ${ }^{69}$ mean that the actual status is often hard to determine - see further section 6.2.

As further confirmation that place names are on the way to becoming DCs, their FM always functions as a modifier of a common noun: ne-wo-pe-o and ne-wo-ki-to are 'new' places as opposed to others (SMs are disputed, though); e-u-de-we-ro is the 'well-visible' ( $\delta \hat{\eta} \lambda o s)$; and $a_{3}-k i-a_{2}-r i-j a$ is 'place by the wavy sea'. ${ }^{70}$

Among the theonyms, $a-n e-m o-i-j e-r e-j a$ 'lady of the wind(s)' and si-to-po-ti-ni-ja 'lady of grain(s)' are particularly noteworthy. The former also occurs as two separate words, ${ }^{71}$ the latter is, so far at least, a hapax, and either or both may, in fact, be uncompounded units. The same may be said for the ceremony po-re-no-zo-te-ri-ja, but the identification of both members is far too disputed to allow morphological conclusions to be drawn. Of similar type are the names of ceremonies to-no-e-ke-te-ri-jo and re-ke-to-ro-te-ri-jo/reke-e-to-ro-te-ri-jo; the latter seems to find a striking parallel in Latin Lectisternium. The SM seems from the root of $\sigma \tau o$ opvuı, but the alternation of re-ke and re-ke-e- needs to be explained. The interpretations proposed consider an alternation of -es- (stem) and -ehe- (dual) or -ehei- (dative/instrumental?). No firm conclusion can be reached and scribal error is possible. Among the divine names, cf. also: a-ta-na-po-ti-ni-ja; e-re-wi-jo-po-ti-ni-ja; ma-ka and pa-si-te-o-i. $m a-k a$ may be $M \hat{\alpha} \Gamma \hat{\alpha}$ (cf. also $\Delta \eta \mu \eta \dot{\tau \eta \rho ?) ~ b u t ~ a g a i n ~ t h e ~ i n t e r p r e t a t i o n ~}$ is very uncertain. Other forms resemble later Greek words: $t i$-ri-se-

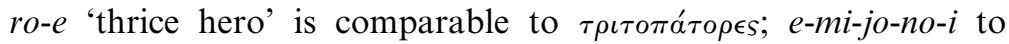

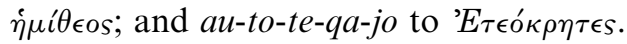

The only Myc. form that can be considered to be of late PIE age is the theonym or title do-po-ta, unanimously interpreted as corresponding to $\delta \epsilon \sigma \pi o^{\prime} \eta s$, a juxtaposition of IE age of the genitive of


problem presented by this form is the root grade of the FM, since **de-po-ta would be expected. Following Schindler 1972: 32, one

${ }^{68}$ Cf. pe-ra-a-ko-ra-i-jo alongside pe-ra $a_{3}-k o-r a-i-j a, p e-r a-k o-r a-i-j a$.

${ }^{69}$ As in wa-no-jo wo-wo; ti-mi-to a-ke-e; o-re-e-wo wo-wo and others.

${ }^{70}$ If FM is to be identified with $\alpha \hat{i} \gamma \epsilon S^{\circ} \tau \dot{\alpha} \kappa \dot{v} \mu \alpha \tau \alpha \Delta \omega \rho \iota \epsilon \hat{\imath}$ (Hsch.). The relationship with the variant $a-k i-a_{2}-r i-j a$ is not clear.

${ }^{71} a-n e-m o-i$-je-re-ja in KN Fp 13, a-ne-mo i-je-re-ja in KN Fp 1 (same scribe). 
might believe that forms such as the original genitive *dém-s survived only outside the paradigm, i.e. in juxtapositions or fixed expressions as Latin paterfamilias, but that 'à l'intérieur du paradigme vivant, *déms fut remplacé cependant par *dm-és'. However, it is evident that do-po-ta, a fixed syntagma and thus exactly the place where we would expect the preservation of the original stem, does not have the e-grade. do- in Myc. results either from the stem in the zero grade (cf. $\delta a ́ \pi \epsilon \delta o \nu$ 'floor of a chamber', a relatively old DC) or is influenced by the paradigmatic word for 'house', attested in Myc. in its root form do-de.

The remaining substantives are forms compounded with a preposition and a noun: $k u-s u-t o-q a$ ( $\xi v \sigma \tau \rho o \varphi \eta$ 'total'). Forms with pan- as FM are common but attested as PNs only: pa-na-re-jo, pa-di-


typical example of a DC. This shows that DCs with adjectival SM and used as adjectives are already a Myc. feature. This is important as the phenomenon of deriving DCs from syntagms of accusative of respect and adjective, attested in Homer, is already Myc.: see above for the ox-name $p o-d a-k o$ 'white-footed' ${ }^{72}$ identical to the Homeric horse name Пó $\delta \rho \gamma o s$, and to-ma-koltu-ma-ko 'white-mouthed' or 'loud-mouthed'. However, true adjectival composition seems severely restricted: only prefixes (such as $\pi \alpha \nu^{-}, \epsilon v^{-}$) appear to be acceptable as FMs.

\subsection{Myc. iterative compounds}

Vedic and Classical Sanskrit attest a compositional category, Āmredita or iterative compounds, deriving from juxtapositions, which may be defined as 'die Wiederholung einer flektierten Nominalform mit Akzentuierung bloß des ersten Gliedes' ( $A i G r$. II,1: 142). Their meaning is typically adverbial and they frequently express an indication of time (divé-dive 'day by day') or place (dámedame 'in every house').

This type, at the very edge of composition, is almost absent within classical Greek: $\pi \alpha ́ \mu \pi \alpha \nu$ 'wholly' may be an example but it is equally

72 Killen 1992a: 103 observes appropriately that po-da-ko as 'swift-footed' 'is not in any event a particularly convincing description for an ox'. 
conceivable that this is a DC with a chance identity of the first and second members. Other forms, such as the pronoun $\alpha \lambda \lambda \eta^{\prime} \lambda \omega \nu$ cannot be defined as 'repetitions', neither semantically ('to one another' is not 'other other') nor morphologically (FM and SM are not identical, FM is not a declined nominal). Over the last few decades, our views as to the age of such compounds have changed considerably. This is due in part to the fact that Hittite has also provided some limited evidence ${ }^{73}$ and Greek, too, now provides a number of examples. There is one Cypriot form ( $a$-ma-ti-a-ma-ti 'every day') ${ }^{74}$ and some Myc. evidence: we-te-i-we-te-i ('year by year') and $a-m o-$ ra-ma ('every day') that can be quoted in this context. This type may thus be an archaic one, ${ }^{75}$ largely lost in later Greek, surely owing, at least partly, to the increased use of prepositional expressions. It also supports the idea that original Āmreditas are formed by the repetition of a case-form: we-te-i-we-te-i is clearly a locative of weto "year'76 and specifies the contribution (do-so-mo) of some individuals. $^{77}$

a-mo-ra-ma has been subject to several interpretations. Docs. ${ }^{2}$ take it as corresponding to Greek $\alpha \rho \mu \alpha \lambda \iota \alpha$ 'rations'. ${ }^{78}$ However, Mühlestein 1968 suggested that the word is an adverbial expression and his interpretation has now received strong support by Killen (forthcoming). If the semantics are clear, the morphological analysis is still difficult. In the literature (DMic., Killen forthcoming), both


first case, one has to assume that the resonant of the suffix in the zero grade undergoes two different treatments, according to its position in the word. This would be surprising for a form that is by definition a repetition of the same word, but it may be just about

73 See Dunkel 1981 with further references.

${ }^{74}$ On an ostrakon dated ca. 600 B.C. from Salamina: Masson 1966: 258.

${ }^{75}$ This slightly changes what was stated by Wackernagel $A i G r$ II,1: 146 (on Avestan and Greek forms) that 'es fraglich ist, ob dieser Typus aus der Grundsprache stammt, während die iterativ-distributive Doppelsetzung beim Zahlwort, beim Pronomen und bei Präpositionen sicher ist'.

${ }^{76}$ Cf. PY Ma 365: $o$-da- $a_{2} k a-k e$-we $a_{2}$-te-ro we-to di-do-si 'and thus the smiths give in the following year', Docs. 294.

${ }^{77}$ PY Es 644.1: ko-pe-re-wo do-so-mo we-te-i-we-te-i GRA T7 ('annual contribution of K.').

${ }^{78}$ The alternation alo would be supported by Hesychius' $\alpha$ ’ $\rho \omega \lambda \lambda$. 
possible $^{79}$ although we would have to assume the presence of $\underset{\circ}{r}$ before a vowel and the whole complex being treated as one word.

The second interpretation was proposed by Peters 1980: 243, n.195a, and the argument was extended by Leukart 1987. Peters argues that the Greek singular form $\hat{\eta} \mu \alpha \rho$ originally alternated with a collective * ${ }^{\prime \prime} \mu \omega \rho .{ }^{80}$ Evidence for this collective form would be Myc. $a-m o-r a-m a$ and the Homeric formula $\nu v ́ \kappa \tau a s ~ \tau \epsilon \kappa a i ~ \hat{\eta} \mu \alpha \rho$, where, Leukart 1987: 358 argues, it seems obvious that $\hat{\eta} \mu \alpha \rho$, with 'visibly [...] plural function' is substituted for an original * $\alpha \mu \omega \rho$ (consistent with the plural $\left.\nu v_{\kappa} \tau \alpha s\right){ }^{81}$ An original /āmōr-āmōrl became lāmōr-āmărl 'mit Ersatz des Hintergliedes durch die synchron regulärere Form' (Peters 1980: 243 n.195a). This is entirely plausible: archaisms are more likely to be preserved in the first member. * $\alpha \mu \omega \rho$ and $\hat{\alpha} \mu \alpha \rho$ must thus have been felt as variants of the same form. The transformation of old collectives into singular forms is a well-attested phenomenon in Greek (cf. $v \delta \omega \rho)$ and is indeed found for this very word in Armenian ( $a w r<* \bar{a} m \bar{o} r$ 'day') ${ }^{82}$ It is possible that the collective meaning had already been lost in Myc. and that of the two free variants * $\alpha \mu \omega \rho$ ceased to be used and is only directly preserved in this compound, with traces still found in Homer. However, in Homer $* \not \alpha \mu \omega \rho$ must have pluralic function, and it is this double function which is otherwise unattested in Greek.

Nonetheless, the solution appears very attractive; regarding the case in which the stem appears, it looks as if it is a straightforward accusative, cf. also the aforementioned $\nu v ́ \kappa \tau \alpha s \tau \epsilon \kappa i \hat{\eta} \mu \alpha \rho$, as well as


ten years'. ${ }^{83}$

${ }^{79}$ For the outcome $o$ in internal position, cf. examples under 6.3.A. For outcome $a$ in final position, cf. a-re-pa $<$ laleiphrl.

${ }^{80}$ Identical alternation found in $\tau \epsilon^{\prime} \kappa \mu \alpha \rho / \tau \epsilon^{\prime} \kappa \mu \omega \rho$, both serving as singulars in Homer.

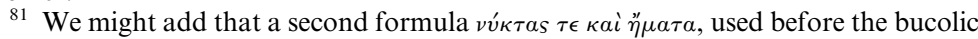
dihaeresis, may be a replacement for the metrically disfavoured (though possible, cf.

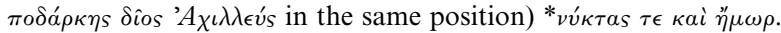

82 Cf. Peters 1980: 243 n.195a, Clackson 1994: 96-97.

${ }^{83}$ Sanskrit provides only one comparable example: áhar-ahar 'year by year'. Alternatively, in view of the frequent use of the locative in iterative compounds indicating time (divé-dive; we-te-i-we-te- $i$ and in particular Cypriot a-ma-ti-a-ma-ti), one might assume that a-mo-ra-ma contains an original endingless locative, cf. Sanskrit áhar(-divi) 'day by day'; FM a locative according to Bartholomae but 


\section{Morphology AND PHONETiCs OF Myc. NC}

\subsection{Kompositionsfuge}

When two words are compounded in Greek, the shape of the compound is dependent on whether the FM ends in a consonant or vowel and on whether the SM begins with a consonant or with a vowel.

A combination FM(V)-SM(C) yields words such as $\mu \eta \lambda \circ \varphi \rho^{\prime} \rho s$

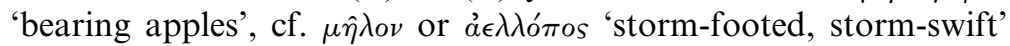
where the stem-vowel is substituted by a compositional vowel, cf. $\alpha_{a}^{\prime} \in \lambda \lambda \alpha$. From a combination FM(V)-SM(V) we have $\sigma \tau \rho \alpha \tau \eta \gamma o ́ s$ (initial vowel of SM lengthened, Wackernagel's Lengthening, see below); under special conditions (like Caland's Law) an internal hiatus is found: $\kappa v \delta \iota \alpha ́ v \epsilon \iota \rho \alpha$. Combinations with $\mathrm{FM}(\mathrm{C})$ are less

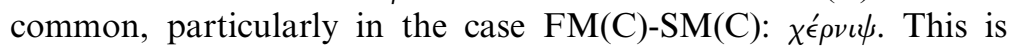
because a consonantal FM can be provided with compositional vowel (and thus belong to the first group).

These categories are principally valid for Myc. as well. But the nature of the writing system (which, crucially, does not distinguish between short and long vowels) and its spelling conventions and a more archaic linguistic stage (see section 6.3.) complicate the picture. In the case of $\mathrm{FM}(\mathrm{V})-\mathrm{SM}(\mathrm{C})$, it is not always possible to ascertain the presence of a compositional vowel, since what is written as $o$ might be the vocalic outcome of a resonant. While $d i$ -

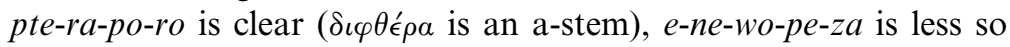
because $o$ can represent either $* o$ or the outcome of $* n_{a}$.

In the case of a combination $\mathrm{FM}(\mathrm{V})-\mathrm{SM}(\mathrm{V})$, there is some indication that Myc. behaves like later Greek. According to the rule formulated by Wackernagel in 1889, the outcome of the encounter between the last vowel of FM and the first of SM is a

contested in $\mathrm{AiGr}$. III,311: 'lokativische Verwendung von -ar ist nicht nachgewiesen (. . . ) áhar-divi und áhar-ahar kann Akk. sein.' Cf. also p. 74: 'In áhar dürfte ein Akk. der Zeitdauer vorliegen, sonst ist Lok. wahrscheinlicher.' Adverbial forms such as

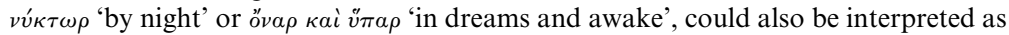
old locatives. However, the paradigmatic locative of áhar is áhan( $i)$ and it is difficult to consider both forms as locatives. In parallel, the Greek adverbs can be understood as accusatives of time. A definitive conclusion seems impossible. 
long vowel showing the same colour as the SM's initial vowel. Standard contraction rules or an original laryngeal do not affect this law. The belief that it applies to Myc. relies on the observation that

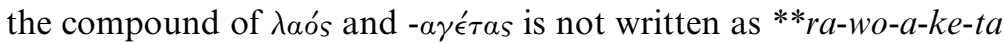
(i.e. with internal hiatus) nor as **ra-wo-ke-ta (with standard contraction), but as ra-wa-ke-ta. ${ }^{84}$ This seems to suggest that the 'contraction' ${ }^{\prime 5}$ is of Wackernagel's type. The alternative interpretation that $r a-w a-k e-t a$ represents $\lambda \alpha_{F}-\alpha \gamma \epsilon \tau \alpha S$ (with elision and absence of lengthening) ${ }^{86}$ is possible but hardly convincing. Cases where Wackernagel's Lengthening does not seem to apply can be explained as juxtapositions, perhaps not even univerbated (de-wero- $\left.a_{3}-k o-r a-i-j a\right)$ or, trivially, as elimination of the hiatus through the introduction of a glide ( $t i-r i$-jo-we: when FM ends in $i$ or $u$ ).

A classification based on the graphic status remains difficult. Furthermore, we must be cautious when drawing conclusions on the basis of the comparison with later Greek alone. A famous case in point is ko-to-no-o-ko where it is contested whether the -o- in no is simply there for graphic reasons or whether it has phonological and indeed morphological significance (see below section 6.3.). Still, some conclusions are possible. Internal hiatus is generally avoided in Myc. through insertion of a glide or through 'contraction' (when possible). Some existing hiatuses are merely graphic: this is the case for all SMs beginning with (etymological) $h$-. Other hiatuses might be ascribed to juxtaposition of two elements: see following section.

\subsection{Word boundary}

The examples just discussed have revealed that despite the possibility of categorising Myc. compounds on a morphological/ phonetic basis, much remains uncertain and fluid. Some categories in particular seem to be subject to more graphic oscillations than others. This is evident for juxtapositions that may not be

\footnotetext{
${ }^{84}$ The difficult and much-discussed question of whether the underlying verb is $\alpha{ }^{\prime} \gamma \omega$ or $\dot{\eta} \gamma \dot{\epsilon}^{\circ} \mu \alpha \iota$ remains.

${ }^{85}$ More precisely, an elision followed by lengthening of the second vowel, given that the supposed 'contraction' does not follow the usual rules. Both terminologies are used in current scholarship, at times in a confused way.

${ }^{86}$ See for example Bader 1971: 158.
} 
univerbated. ${ }^{87}$ Close syntactic and semantic units are often written as one word. This is especially frequent in divine names (cf. pa-si-te$o-i$ ), without having any further significance. ${ }^{88}$ The opposite, namely the graphic division of compounds, also occurs (e.g. ke-re-si-jo, we-ke). ${ }^{89}$ This is rare and there are always compelling epigraphic or linguistic reasons for this. In particular, Simkin 1999 has demonstrated that the tendency of hand 2 at Pylos in the Ta series to separate compounds graphically, e.g. e-ne-wo-pe-za written as $e-n e-$ $w o, p e-z a$, is a conscious analysis of the members of this compound, the reason being that it was created at that moment. He notes that the Ta series is a one-off, unusual survey; the compound is used to describe a piece of furniture, and a table 'with nine feet' is rather uncommon.

This is aggravated by the fact that, particularly in Knossos, the word divider is often used irregularly and it is often simply impossible to tell whether a given sequence is a compound or not.

\subsection{Compositional vowel}

In Greek, a FM can be represented by either a simple stem (consonantal or vocalic) or a stem provided with a non-etymological vowel. This vowel can be added to a stem ending in consonant/

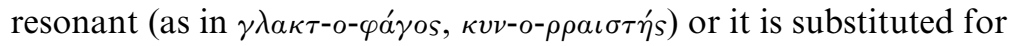

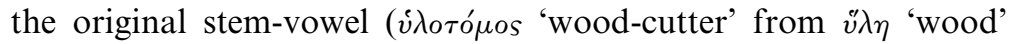
etc). By far the most common compositional vowel is $o$, but $\alpha, \eta$, a and $\iota$ are also used.

Scholars are usually sceptical ${ }^{90}$ when it comes to the existence of a compositional vowel in Myc. because it is considered a morphological innovation and some very old looking compounds do not contain it, e.g. ke-ni-qa $\chi \epsilon ́ \rho-\nu \iota \psi$ 'hand-basin'. No unambiguous example for a compositional vowel o has, as yet, surfaced, but the simple observation that it is a highly frequent phenomenon in

87 Among toponyms: de-we-ro- $a_{3}-k o-r a-j a$, pe-ra- $a_{3}-k o-r a-j a$, o-re-mo-a-ke-re-u; and cf. also re-ke-e-to-ro-te-ri-jo.

${ }^{88}$ Cf. Duhoux 1999: 232ff., Simkin 1999: 10ff.

${ }^{89}$ Cf. Duhoux 1999: 220ff., Simkin 1999: 4ff.

${ }^{90}$ Most prominently Heubeck 1963: 14 and 1971: 61, also Lejeune Mém. II $173-177$. 
Homer should suggest that its starting point is very old. A consideration of some Myc. evidence will be useful:

A. ke-ro-ke-re-we-o; a-re-pa-zo-ola-re-po-zo-o; ma-to-ro-pu-ro; a-no-me-de?; a-pu-ko-wo-ko.

B. se-re-mo-ka-ra-o-re; a-ne-mo-i-je-re-ja; di-wo-pu-ka-ta; ma-toro-pu-ro?

C. ko-to-no-o-ko; $a_{3}-k i-p a-t a ; \quad a_{3}-k i-p o ; \quad a_{3}-k i-p o-d e ; a_{3}-k i-n o-o$;; $a_{3}$-ki-wa-ro?; $a_{3}$-ki-wa-to?; possibly also e-to-wo-ko, tu-wo-te-to.

The majority of examples under A may show the outcome of a vocalic resonant rather than a purely morphological compositional vowel. This is supported by the alternation $a$-re-pa-zo-ola-re-po-zo-o and by ma-to-ro-pu-ro (to be read as </aleip ${ }_{n}^{h}$-/ and /mātr-/). This situation may well have been one of the starting points for the spread of $o$ as the most common compositional vowel in Greek (and $a-r e-p o-z o-o$ is matched by aipo- as opposed to aî $\mu$ ). a-pu-ko-wo-ko is different, since the presence of $o$ may (or may not) be ascribed to pure graphic reasons and represent lampuk-worgoil, with anticipation of the first vowel of SM to the FM ending in consonant, cf. spellings such as to-qi-de-we-sa.

Forms under B may show a compositional vowel; but it is at least equally possible that $o$ represents a case, especially considering that they are all DCs and as such possibly juxtapositions of a genitive and a noun (see above).

The examples under $\mathrm{C}$ are the most likely candidates for containing a compositional vowel. This seems clearest in the examples containing a compositional vowel $i$. Consider the case of $a_{3}-k i$-pa-ta 'goat-herd'. The interpretation of the SM is disputed ${ }^{91}$ but it is hard to see what else $a_{3}-k i$ - should contain other than airc-. It would thus appear that Myc. shares significant innovations with later Greek.

ko-to-no-o-ko is more difficult. At first, it seems a straightforward

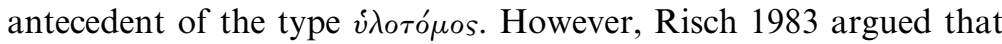
the word is thus written to keep the constituent elements of the compound graphically separate, i.e. that we should read this as /ktoin- ${ }^{h}{ }^{h}{ }^{h} o s /$. In other words, the -o- in -no- is a 'dead', purely

${ }^{91}$ Though it seems most straightforward to derive it from * $p e h_{2}$ - 'hüten, weiden', cf. $L I V$ s.v. 
graphic vowel. But it is not clear why this should have happened, and the scribes regularly write forms such as re-u-ko-nu-ka, po-ki-ro$n u-k a$. Also, it is noteworthy that, leaving apart the uncertain case of

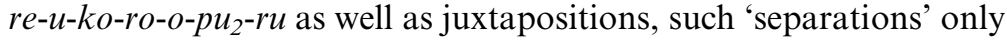
seem to occur where the SM, historically speaking, begins with $h-^{92}$ and if Risch were right, this distribution would remain unexplained.

This inevitably raises the question as to the age of o-stem compounds from a-stem nouns. The situation in Homer is almost evenly split: 6 compounds show $-\eta$ - (type $\beta$ ov $\lambda \eta \varphi$ ó $\rho$ os), 8 compounds

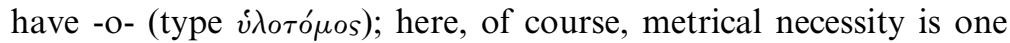
factor. In Myc. we find ko-to-no-o-ko as well as di-pte-ra-po-ro. In Sanskrit, both $-a$ - and $-\bar{a}$ - are found. The traditional view is, of course, that the forms with a long vowel are secondary. Wackernagel $A i G r$ II,1: 49, however, believed that '[S]chon die Grundsprache wechselte in derartigen femininischen Vordergliedern zwischen $\bar{a}$ und $\breve{o}$ als Stammausgang.' Of course, the grammatical gender system of PIE has been reinterpreted since Wackernagel's times and for 'feminine' we should now read 'collective'. In the light of this, Leukart 1994: 315 plausibly argued that in ko-to-no-o-ko, the $o$, far from being a secondary compositional vowel, could be a morphological witness for the base form *ktoino-. But his view that this replacement was the standard procedure may be modified. For at some stage, the collectives will have been a derivational rather than a paradigmatic category, in other words, they were autonomous lexemes. It is only to be expected that in some cases at least, this was used as the basis for compounds and derivatives, ${ }^{93}$ in other cases, the singulative may have been used, and when the whole gender, number and declensional system was realigned, it could appear as though feminine a-stems were replaced by o-stems in composition. This would explain why in the early-attested IE languages both options are exploited. There is thus no need to assume that the -o- in ko-to-no-o-ko represents an inner-Greek morphological innovation and thus no need to explain it away as Risch tried to do. The last two examples in this list equally contain a graphic - $o-$. However, it is not clear whether this represents -os or the

92 This would have obvious repercussions for the dating of Grassmann's Law which may well be post-Mycenaean; see also Plath 1987.

${ }^{93} \mathrm{Cf}$. for the type Ved. rtấvan- Tichy 1986. 
thematic - $O$-. If the latter, this would indeed be a morphological innovation as there is no historical justification for the thematic vowel in this instance. The graphic system does not permit a decision but it is worth pointing out that in Homer, no other stems, not even stems in a stop, are as prone to replacing the suffix with the thematic vowel as the s-stems are.

\subsection{Shape of FM and $S M$}

Some words - particularly verbal stems - are found used in both FM and SM. Their shape varies according to their position in the compound (for example, FMs can be elided and SMs provided with a suffix) or to the syntactical structure (e.g. $e$ grade in $\varphi \epsilon \rho$ évıкos

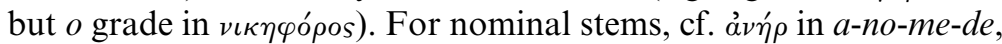
$a-n o-q o-t a$, possibly $a-n o-q a-s i-j a$; and as SM in ka-wa-do-ro (if /kalw-andros/), ke-sa-da-ra and a-re-ka-sa-da-ra; and me-ta-no,


$k o$; vâेs in na-u-si-ke-re-we and na-u-do-mo: o-ku-na-wo and e-u-nawo. ä $\sigma \tau v$ is represented in $w a-t u-o-k o$ and as SM possibly in $a-k e-w a-$ ta, $a_{3}$-ki-wa-to (laigi-wastos/?), ne-ri-wa-to. $\delta \hat{\eta} \mu o s$ is common as both FM (da-mo-ko-ro) and SM (e-u-ru-da-mo; a-ko-ro-da-mo-jo; $e-u-d a-m o)$.

Ablaut variations in verbal stems are very common and are as expected: $\varphi \epsilon \rho$-/ $\varphi \rho \rho$ - in a-pi-po-re-we and di-pte-ra-po-ro as opposed to pe-re-qo-no (if $/ p^{h}$ ere- $k^{w h}$ onos/); $\epsilon \chi \epsilon-/ o \chi o-$ in $e-k e-m e-d e$ and ko-to$n o-o-k o ; \nu \epsilon \sigma-/ \nu o \sigma-\left(\nu \epsilon^{\prime} \mu a \iota\right)$ in ne-ti-ja-no and wi-pi-no-o (if no-o is



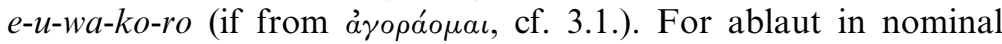
stems, cf. $\pi \epsilon \delta-/ \pi o \delta$ - in e-ne-wo-pe-za and po-ru-po-de, $a_{3}-k i-p o-d e$.

\section{CONCLUSIONS}

A comparison between Myc. and later Greek compositional categories has confirmed that from the point of view of $\mathrm{NC}$ these two stages of the language bear a coherent relationship to one another. Some conclusions were expected: for example, that Myc. is in many respects more archaic than later Greek, cf. in particular the status of DCs, the compositional vowel (not yet widespread but 
present in a-stems) and the retention of iterative compounds, which (with exception of Cypriot $a-m a-t i-a-m a-t i$ ) do not survive into historical Greek.

On the other hand, a closer investigation of compositional patterns and semantics has revealed that both forms of the language share a considerable number of innovations, in particular the existence of the $\pi$ ó $\delta \alpha \rho \gamma o s$ type. A second consideration is that Myc. demonstrates how traditional ideas on $\mathrm{NC}$ as 'poetic', peculiar of high style, must at least be modified. Otherwise (i.e. literary) high-style compounds are used in Myc. to characterise common objects (as po-ki-ro-nu-ka, formally


with surprising frequency.

It has also been argued that people of high status in Myc. have compounded names, while those of lower level have single names. If true, this would lend weight to the theory that composition is 'high level'. However, within the same 'social class' both simple and compounded names seem to be found, e.g. a-re-ku-tu-ru-wo


many of the seemingly single names are not understood and may represent a pre-Greek layer. It is clear that while we can discuss the etymology of PNs, their value as evidence for $\mathrm{NC}$ is limited. The fact remains that compounds are not only found in PNs, but also in appellatives. These latter are represented in all the categories, with a


and of Bs. It is possible, at times, to state that a certain category is represented by only PNs as in the ' $E_{\chi} \epsilon$ ' $\pi \omega \lambda$ os and $\tau \epsilon \rho \psi \psi_{i}^{\prime} \mu \beta \rho o \tau o s$ types and thus perhaps infer that it is of higher style than another. However, as already stressed, the Myc. evidence is biased in favour of PNs: we cannot be sure of the status of these categories outside PNs. On the other hand, some other categories such as VGCs and DCs are mostly constituted by substantives, Bs by PNs and adjectives. It is evident that a distinction between high level and standard level cannot be made on the basis of compositional categories either.

At present, it seems unwise to draw further conclusions as to the status of NC as a literary tool. An exhaustive study of NC in Greek inscriptions and low-level texts would help to either confirm this 
scenario or change it from the point of view of first-millennium Greek.

\author{
Torsten Meißner; Olga Tribulato \\ Pembroke College \\ Cambridge \\ CB2 1RF, UK \\ email:tm10012@cam.ac.uk; ormt2@cam.ac.uk
}

\title{
TEXTS AND DICTIONARIES
}

Acta Mycenaea: Acta Mycenaea. Proceedings of the fifth international colloquium on Mycenaean studies, held in Salamanca, 30 March-3 April 1970. Martín S. Ruipérez ed. Vol. I-II, Salamanca: Universidad de Salamanca; (Vol. I = Minos 11 [1970]; Vol. II: Minos 12 [1971]).

AiGr: Jacob Wackernagel (et al.), Altindische Grammatik. II,1: Einleitung zur Wortlehre. Nominalkomposition; III: Nominalflexion-Zahlwort-Pronomen, Göttingen: Vandenhoeck\&Ruprecht 1896-.

Atti Roma: Atti e memorie del primo congresso internazionale di micenologia. Roma, 27 Settembre-3 Ottobre 1967. Roma: Edizioni dell'Ateneo 1968.

$D E G$ : Pierre Chantraine, Dictionnaire étymologique de la langue grecque. Histoire des mots, 2 vols., Paris: Klincksieck, nouveau tirage 1983-1984.

DMic: Francisco Aura Jorro, Diccionario micénico, Madrid: Istituto de Filología 1985-1993.

Docs.: Michael Ventris - John Chadwick, Documents in Mycenaean Greek, Cambridge: CUP 1956.

Docs. $^{2}$ : Michael Ventris - John Chadwick, Documents in Mycenaean Greek, second edition by John Chadwick, Cambridge: CUP 1973.

Floreant Studia Mycenaea: Floreant Studia Mycenaea. Akten des X. Internationalen Mykenologischen Colloquiums in Salzburg vom 1.-5. Mai 1995. Siegrid DegerJalkotzy - Stefan Hiller - Oswald Panagl edd., Wien: Verlag der Österreichischen Akademie der Wissenschaften 1999.

Lejeune, Michel, Mém: Mémoires de philologie mycénienne I Paris: CNRS 1958; II Roma: Edizioni dell'Ateneo 1971.

LIV: Lexikon der indogermanischen Verben, Helmut Rix ed., Wiesbaden: Reichert 1998.

Mykenaïka: Mykenaïka. Actes du IX Colloque international sur les textes mycéniens et égéens organisé par le Centre de l'Antiquité Grecque et Romaine de la Fondation Hellénique des Recherches Scientifiques et l'École Française d'Athènes (Athènes, 2-6 octobre 1990), Jean-Pierre Olivier ed., BCH Suppl. 25, 1992.

Res Mycenaeae: Res Mycenaeae. Akten des VII. Internationalen Mykenologischen Colloquiums in Nürnberg vom 6.-10. April 1981. Alfred Heubeck - Günter Neumann edd. Göttingen: Vandenhoeck \& Ruprecht 1983.

Studies Chadwick: Studies in Mycenaean and Classical Greek Presented to John Chadwick. John T. Killen - José Melena - Jean-Pierre Olivier edd., Minos 20-21, 1987. 
Studies Killen: A-na-qo-ta. Studies Presented to J.T. Killen, John Bennet - Jan Driessen edd. Minos 33-34, 1998-99.

Tractata Mycenaea: Tractata Mycenaea. Proceedings of the eight international colloquium on Mycenaean studies, held in Ohrid, 15-20 September 1985. Petar Hr. Ilievski - Ljiljana Crepajac edd. Skopje: Macedonian Academy of Sciences and Arts 1987.

\section{REFERENCES}

BADER, FranÇOISE, 1965. Les composés grecs du type de demiourgos, Paris: Librarie C. Klincksieck.

BADER, FranÇOISE, 1969. Études de composition nominale en mycénien, Roma: Edizioni dell'Ateneo.

BADER, FrançOISE, 1971. 'Le traitement des hiatus à la jointure des deux membres d'un composé nominal en mycénien', in Acta Mycenaea II, 141-196.

Bartonek, Antonín, 1999. 'Mycenaean Common Nouns in the Disguise of Proper Names', in Floreant Studia Mycenaea, 121-130.

Benveniste, Emile, 1967. 'Fondements syntaxiques de la composition nominale', Bulletin de la Société de Linguistique de Paris 72, 15-31.

Benveniste, Emile, 1973. Origines de la formation des noms en indo-européen, Paris: Librarie d'Amérique et d'Orient.

Bielecki, François-JosePh, 1899. Les mots composés dans Eschyle et dans Aristophane: étude litéraire et grammaticale, Luxembourg: Beffort.

Buzalkovska-Aleksova, Margarita, 1999. 'Some parallel elements in Mycenaean compounds-appellatives and personal names', in Floreant Studia Mycenaea, $177-184$.

Cassio, Albio C., 1991. 'La piu' antica iscrizione di Cuma e $\tau i v(v) v \mu a \iota$ in Omero', Die Sprache 35, 187-208.

Chadwick, John, 1996-1997. 'Three Temporal Clauses', Minos 31-32, 293-301.

Christ, HAns, 1890. Die verbalen Abhängigkeitskomposita des Griechischen, München: Sitzungsberichte der bairischen Akademie der Wissenschaften, phil. Klasse, I, 143-246.

Clackson, James, 1994. The Linguistic Relationship Between Armenian and Greek, Oxford-Cambridge (Mass.): Blackwell.

Clemm, Wilhelm, 1867. De compositis Graecis quae a verbis incipiunt, Phil. Diss. Giessen.

Clemm, Wilhelm, 1875. 'Die neusten Forschungen auf dem Gebiet der griechischen Composita' Curtius Studien VII, Leipzig, 1-99.

Da Costa Ramalho, Americo, 1952. Suplemento de Humanitas vol. IV, Coimbra.

Debrunner, Albert, 1917. Griechische Wortbildungslehre, Heidelberg: Winter.

Doria, MARIo, 1965. Avviamento allo studio del miceneo, Roma: Edizioni dell'Ateneo.

Duhoux, Yves, 1999. 'La séparation des mots en linéaire B', in Floreant Studia Mycenaea, 227-236.

Dunkel, George E., 1981. 'Āmredita and iteration of preverbs in Vedic and Hittite', Zeitschrift für vergleichende Sprachforschung 95, 214-226.


Glotta 70, 197-225.

Dunkel, George E., 1999. On the origins of nominal composition in Indo-European, in 
Compositiones Indogermanicae in memoriam Jochem Schindler, Heiner Eichner Hans C. Luschützky edd., Praha: Enigma.

Forster, HANs, 1950. Zur Geschichte der griechischen Komposita vom Typ émíxpvoos, Zürich: Aschmann \& Scheller.

Frei-Lüthy, Christine, 1978. Der Einfluß der griechischen Personennamen auf die Wortbildung, Heidelberg: Winter.

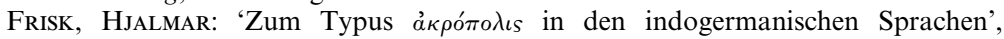
Indogermanische Forschungen 52, 282-296.

Glaser, Max, 1898. Die zusammengesetzten Nomina bei Pindar, Amberg: Lindl.

GeORGIEV, Vladimir I., 1971. 'Le traitement des sonantes voyelles indo-européennes et le problème du caractère de la langue mycénienne', in Acta Mycenaea II, 361-380.

Hatzidakis, Georg N., 1900. 'Zur Betonung der griechischen Composita deren zweiter Theil ein Verbaladjektiv trochäischer Messung ist', Berichte der Königl. Preuß. Akad. d. Wissenschaften zu Berlin, vol. I, 418-423.

Heubeck, Alfred, 1963. 'Myk. a 3 -ki-pa-ta 'Ziegenhirt', Indogermanische Forschungen $68,13-21$.

Heubeck, Alfred, 1972. 'Syllabic $r$ in Mycenaean Greek?', in Acta Mycenaea II, 55-79.

Holmes, David H., 1893. The limitations of the composition of verbs with prepositions in Thucydides, Phil. Diss. Baltimore.

Ilievski, Petar Hr., 1983. 'Some Structural Peculiarities of Mycenaean-Greek Personal Names', in Res Mycenaeae 202-215.

von Kamptz, Hans, 1982. Homerische Personennamen, Göttingen: Vandenhoeck \& Ruprecht.

KARASSEK, JoSEPH, 1880. Über die zusammengesetzten Nomina bei Herodot. Saaz: Kais. Kön. Staats-Ober-Gymnasium.

Killen, John T., 1992a. 'The Oxen's Names on the Knossos Ch Tablets', Minos 27-28, 101-108.

Killen, John T., 1992b. 'Ke-u-po-da e-sa-re-u and the Exemptions of the Pylos Na Tablets', Minos 27-28, 109-123.

KILlEN, JoHN T., 1992c. 'Observations on the Thebes Sealings', in Mykenaïka, $365-380$.

Killen, John T., 1999. 'New Readings and Interpretations in the Pylos Tablets', in Floreant Studia Mycenaea, 343-353.

Killen, John T., ForthCOMING. 'Two notes on Linear B' to appear in Živa Antika.

KNECHT, THEODOR, 1946. Geschichte der griechischen Komposita vom Typ $\tau \epsilon \rho \psi$ í $\mu \beta \rho \tau o s$, Biel: s.n.

Lanman, Charles R., 1878. 'A Statistical Account of Noun-Inflection in the Veda', Journal of the American Oriental Society 10, 325-600.

LANDAU, OsKar, 1958. Mykenisch-griechische Personennamen, Göteborg: Almqvist \& Wiksell.

LeJeune, Michel, 1957. 'Mycénien da-ma, du-ma 'intendant', Minos 5, 130-148 (= Mémoires de philologie mycénienne I, 187-201).

LeJeune, Michel, 1958. 'Observations sur les composés privatifs', Revue Philologique 32, 198-205 (= Mémoires de philologie mycénienne II 37-45).

LeJeune, Michel, 1972. Phonétique historique du mycénien et du grec ancien, Paris: Klincksieck.

LeUKART, Alex, 1987. 'po-ro-qa-ta-jo, to-sa-pe-mo, a-mo-ra-ma and Others: Further 
Evidence for Proto-Greek Collective Formations in Mycenaean and Early Alphabetic Greek', in Studies Chadwick 343-366.

Leukart, AleX, 1994. Die frühgriechischen Nomina auf-tas und-as, Wien: Verlag der Österreichischen Akademie der Wissenschaften.

MacDonell, Arthur A., 1916 ${ }^{3}$. A Vedic Grammar for Students, Oxford: Clarendon Press.

Magnien, Victor, 1927. 'Les composés dans la langue et la pensée homériques', Raccolta di scritti in onore di Felice Ramorino, Milano: Vita e pensiero, 27-48.

Masson, Olivier, 1966. 'A propos de deux formules redublées au locatif', Živa Antika 15, 257-266.

MeIER-BRÜGGER, Michael, 1992. Griechische Sprachwissenschaft, vol. I-II, Berlin/ New York: de Gruyter.

Meillet, Antoine \& Vendryès, Joseph, 1963. Traité de grammaire comparée des langues classiques, 3rd edition, Paris: Champion.

Melena, José L., 2001. Textos griegos micénicos comentados, Vitoria-Gasteiz: Xavier María de Munibe.

Morpurgo Davies, Anna, 1968. 'The Treatment of $*_{\mathrm{r}}$ and $*_{1}$ in Mycenaean and Arcado-Cyprian', in Atti Roma 791-814.

Morpurgo Davies, Anna, 1971. 'Greek and Indo-European Semi-Consonants: Mycenaean $u$ and w', in Acta Mycenaea II, 80-121.

Morpurgo Davies, Anna, 1983. 'Mycenaean and Greek Prepositions: o-pi, e-pi etc.', in Res Mycenaeae, 287-310.

Morpurgo Davies, Anna, 1987. 'Mycenaean and Greek Syllabification', in Tractata Mycenaea, 91-104.

Morpurgo Davies, Anna, 1999. 'The Morphology of Personal Names in Mycenaean and Greek: Some Observations', in Floreant Studia Mycenaea, 389-407.

MüHlestein, Hugo, 1958. 'Einige mykenische Wörter', Museum Helveticum 15, $222-226$.

NeCKel, Отто, 1882. De nominibus Graecis compositis, quorum prior pars casuum formas continet, Leipzig: s.n.

PAlmer, Leonard R., 1963. The Interpretation of Mycenaean Greek Texts, Oxford: Clarendon Press.

Peters, MARTIN, 1980. Untersuchungen zur Vertretung der indogermanischen Laryngale im Griechischen, Wien: Verlag der Österreichischen Akademie der Wissenschaften.

PetrušEvski, Mihail D., 1965. 'Pour la valeur AU du signe *85', Kadmos 4, 121-128.

Plath, Robert, 1987. 'Hauchdissimilation im Mykenischen?', Münchener Studien zur Sprachwissenschaft 48, 187-193.

RichaRds, GeORGE C., 1918. 'Greek compound-adjectives with a verbal element in tragedy', Classical Quarterly 12, 15-21.

RIECK CARL, 1877. De adiectivorum compositorum usu Euripideo, Neu-Strelitz: Gymnasium Carolinum.

RisCH, ERnst, 1944. 'Griechische Determinativkomposita', Indogermanische Forschungen 59, 1, 1-61 (= Kleine Schriften 1-61).

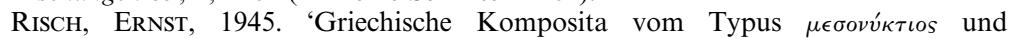

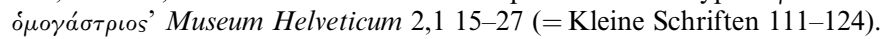

Risch, ERnST, 1949. 'Griechische Determinativkomposita III. Teil', Indogermanische Forschungen 59, 3 245-294 (= Kleine Schriften 62-111).

Risch, ERnst, 1974. Wortbildung der homerischen Sprache, Berlin-New York: de Gruyter. 
Risch, ERnST, 1983. Probleme bei der Schreibung von Hiat und Kompositionsfuge im Mykenischen, in Res Mycenaeae 374-390.

Risch, ERnst, 1987. Die mykenischen Personennamen auf-e, in Tractata Mycenaea 281-298.

RoEMHELD, Friedrich, 1877. De epithetorum compositorum apud Euripidem usu et formatione, Giessen: Ricker.

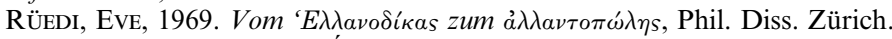

RuIJGH, CoRnelis J., 1967. Études sur la grammaire et le vocabulaire du grec mycénien, Amsterdam: Hakkert.

RuiJgh, CoRnelis J., 1987. 'da-ma/du-ma et l'abréviation DA, notamment in PY En 609.1', in Tractata Mycenaea, 299-322.

Ruijgh, CoRnelis J., 1983. 'Observations sur les neuters en -s/h-', in Res Mycenaeae $391-407$.

Scarlata, Salvatore, 1999. Die Wurzelkomposita im Rg-Veda, Wiesbaden: Reichert.

SCHINDLER, JoCHEM, 1972. 'L'apophonie des noms-racines indo-européens', Bulletin de la Société de Linguistique de Paris 67, 31-38.

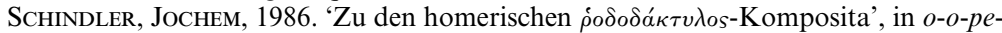
ro-si, Festschrift für Ernst Risch zum 75. Geburtstag, ed. Annemarie Etter, Berlin/ New York: de Gruyter.

SCHINDLER, JoCHEM, 1997. 'Zur internen Syntax der indogermanischen Nominalkomposita' In: Berthold Delbrück y la sintaxis indoeuropea hoy. Actas del Coloquio de la Indogermanische Gesellschaft Madrid, 21-24 de septiembre de 1994, ed. Emilio Crespo y José Luis García Ramón. Madrid/Wiesbaden: Reichert 1997, 537 540 .

VON SCHROEDER, LEOPOLD, 1877. 'Die Accentgesetze der homerischen Nominalkomposita, dargestellt und mit denen des Veda verglichen', Zeitschrift für vergleichende Sprachforschung 24, 101-148.

Schultz, HeRmann, 1882. Quae nova Sophocles protulerit nomina composita, Königsberg: Hartung.

SCHWYZER, EdUARD, 1939. Griechische Grammatik, München: Beck.

Simkin, Oliver B., 1999. Word Division in Linear B, M.Phil. essay, Cambridge.

SOMmer, FERDINAND, 1948. Zur Geschichte der griechischen Nominalkomposita, München: Verlag der Bayerischen Akademie der Wissenschaften.

Stolz, Friedrich, 1874. Die zusammengesetzten Nomina in den Homerischen und Hesiodischen Gedichten, Klagenfurt: Leon.

van Strien-Gerritsen, Magdalena, 1973. De Homerische composita, Assen: van Gorcum.

Tessing, Sven, 1884. De compositis nominibus Aeschyleis et Pindaricis, Lund: Ohlsson.

Thompson, Rupert, 1999. 'Bulls' Testicles and Mycenaean Onomastics: Must 'I $\mathrm{s} \iota \mathrm{Be}$ Singular?', in Studies Killen, 339-348.

Tichy, Eva, 1986. 'Vedisch rtấvan- und avestisch aș̆auuan-', Die Sprache 32, 91-105.

Troxler, Hans, 1964. Sprache und Wortschatz Hesiods, Zürich: Juris.


Sakellarios.

Uhlich, Jürgen, 1993. Die Morphologie der komponierten Personennamen des Altirischen, Witterschlick/Bonn: Wehle.

Wachter, Rudolf, 1990. 'Nereiden und Neoanalyse. Ein Blick hinter die Ilias', Würzburger Jahrbücher 16, 19-31. 
WaCKeRnagel, JACOB, 1889. Das Dehnungsgesetz der griechischen Composita, Basel: Reinhardt (= Kleine Schriften 897-961).

Williger, EDUARD, 1928. Sprachliche Untersuchungen zu den Komposita des Griechischen des fünften Jahrhunderts, Göttingen: Vandenhoeck \& Ruprecht.

ZACHER, KonRAD, 1886. Zur griechischen Nominalkomposition, Breslau: Koebner. 